\title{
ASYMMETRIC WAGE ADJUSTMENT AND EMPLOYMENT IN EUROPEAN FIRMS
}

\section{PETRA MAROTZKE, ROBERT ANDERTON, ANA BAIRRÃO, CLÉMENCE BERSON, PETER TÓTH}


(c) National Bank of Slovakia

www.nbs.sk

Imricha Karvaša 1

81325 Bratislava

research@nbs.sk

October 2017

ISSN $1337-5830$

The views and results presented in this paper are those of the authors and do not necessarily represent the official opinion of the National Bank of Slovakia.

All rights reserved. 


\title{
Asymmetric wage adjustment and employment in European firms ${ }^{1}$
}

\author{
Working paper NBS
}

Petra Marotzke ${ }^{2}$, Robert Anderton ${ }^{3}$, Ana Bairrão ${ }^{4}$, Clémence Berson ${ }^{5}$, Peter Tóth ${ }^{6}$

\begin{abstract}
We explore the impact of wage adjustment on employment with a focus on the role of downward nominal wage rigidities. We use a harmonised survey dataset, which covers 25 European countries in the period 2010-2013. These data are particularly useful given the firm-level information on the change in economic conditions and collective pay agreements. Our findings confirm the presence of wage rigidities in Europe: first, collective pay agreements reduce the probability of downward wage adjustment; second, wage responses to demand developments are asymmetric with a weaker downward response. Further, estimation results point to a negative effect of downward nominal wage rigidities on employment at the firm level.
\end{abstract}

JEL classification: J23; J30

Keywords: Wage rigidity, Employment, Demand shocks

Downloadable at http://www.nbs.sk/en/publications-issued-by-the-nbs/working-papers

\footnotetext{
${ }^{1}$ We are grateful to Andreja Pufnik for help in compiling the literature. We also thank the anonymous referee, WDN participants and seminar participants at Bundesbank (April 2016), the ECB (June 2016), the Eurosystem's Working Group on Forecasting meeting in Frankfurt (September 2016), Eesti Pank (September 2016) and the AMSE-Banque de France Labour Market Conference (December 2016) for their useful comments. The paper represents the authors' personal opinions and does not necessarily reflect the views of the institutions with which they are affiliated.

${ }^{2}$ Deutsche Bundesbank, Frankfurt am Main, Germany; petra.marotzke@bundesbank.de

${ }^{3}$ European Central Bank, Frankfurt am Main, Germany; University of Nottingham, Nottingham, United Kingdom; robert.anderton@ecb.europa.eu

${ }^{4}$ raquelbairrao@gmail.com

${ }^{5}$ Banque de France, University Paris 1, Paris, France; clemence.berson@banque-france.fr

${ }^{6}$ Národná banka Slovenska, Bratislava, Slovakia; peter.toth@nbs.sk
} 


\section{NON-TECHNICAL SUMMARY}

This paper empirically explores the behaviour of wages and the impact of wage adjustment on employment in Europe during the years 2010 to 2013, with a focus on the role of nominal rigidities. The analysis is based on new harmonised firm-level survey data from the Wage Dynamics Network - a European System of Central Banks research network. One major advantage of the WDN data when exploring wage and employment adjustments is firm-level information on the change in economic conditions during the 2010-to-2013 period.

Our analysis differs from previous studies in the way we identify downward nominal wage rigidity. We estimate an ordered probit model of wage adjustments and find evidence in favour of the presence of wage rigidities in Europe. First, collective pay agreements increase the probability of a base wage raise and lower the probability of unchanged wages or a decrease in wages. This suggests that the wage bargaining process impacts the degree of downward nominal wage rigidity. This result also implies significantly more downward nominal wage rigidities for countries with much higher shares of employees covered by collective pay agreements (with the latter mainly driven by agreements outside the firm, i.e., national or sectoral, rather than more decentralised firm-level agreements).

Second, wage responses to demand developments are asymmetric, as a fall in demand increases the likelihood of falling wages to a significantly lesser extent than a rise in demand increases the probability of wages going up (Figure 1). Furthermore, a strong and moderate fall in demand significantly increases the probability that base wages will remain unchanged. This is further evidence of downward nominal wage rigidity, as the distribution of changes in wages starts to bunch around unchanged base wages when demand falls. By contrast, when there is a moderate or strong increase in demand, the probability of base wages staying unchanged goes down (Figure 1).

\section{Figure 1. The effect of demand on wages}

(changes in probability in p.p.)

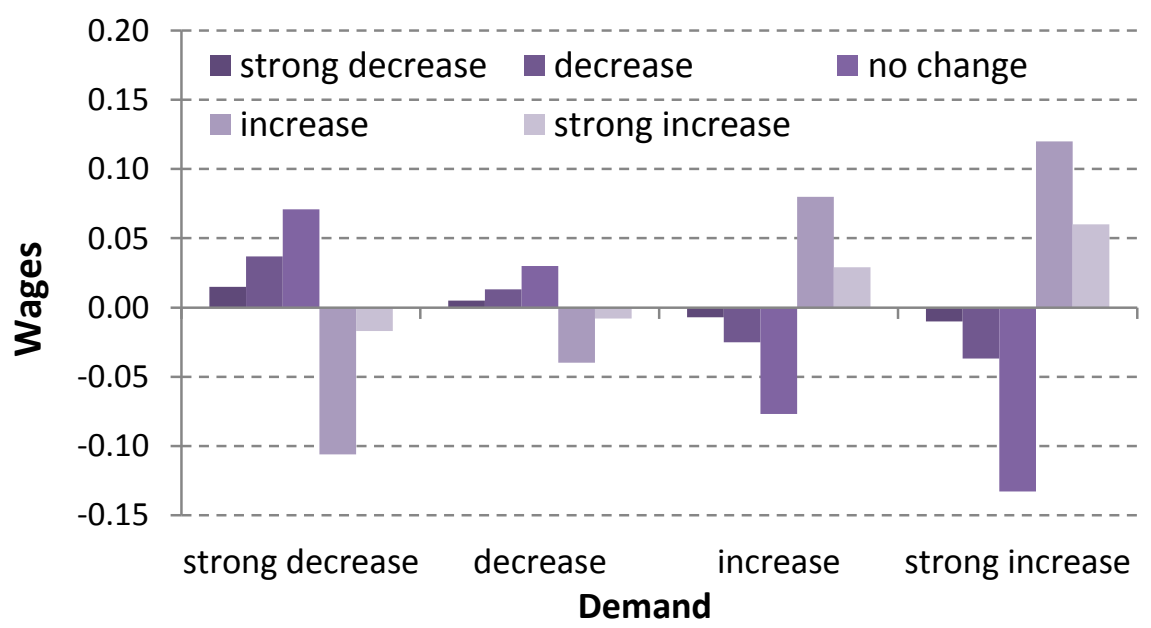

Note: Changes in probability compared to the baseline of no change in demand. 
We further explore the influence of wage reactions to a fall in demand on employment. To take the endogeneity of wages in the employment equation into account, we use the share of workers covered by a collective pay agreement as an instrumental variable for wage adjustments. Estimation results point to a negative effect of downward wage rigidities on employment at the firm level, when these rigidities are induced by collective pay agreements. We find that wage adjustments have a significant effect on employment within the firm. The probability that employment falls or remains unchanged is significantly lower when wages decrease compared to the reference category of unchanged base wages. If wages increase, the probability of a decrease in employment is higher than under unchanged wages (Figure 2).

Figure 2. The effect of wages on employment following a drop in demand (changes in probability in p.p.)

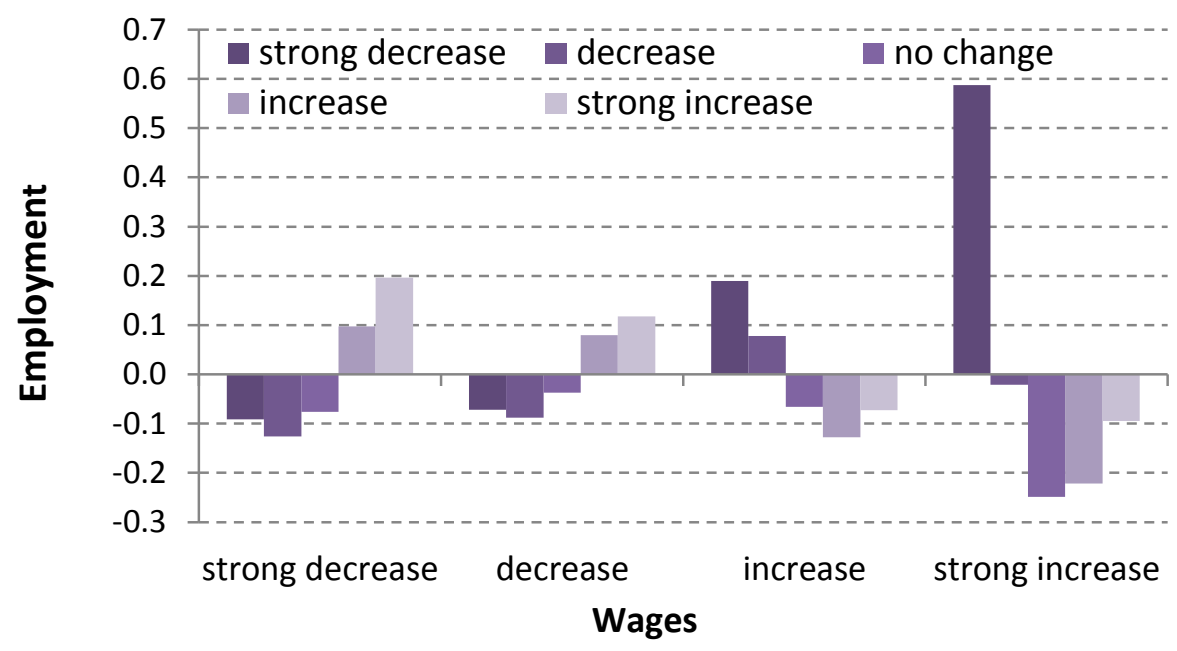

Note: Changes in probability compared to the baseline of no change in wages.

Wages and employment depend on similar economic circumstances. A decrease in the availability of supplies from the firm's usual suppliers, in the customers' ability to pay and meet contractual terms, or in the access to external financing affects wages and employment negatively. Moreover, firms that use flexible wage components are less likely to reduce wages and employment. This suggests that some firms tend to use bonuses as a buffer to avoid base wage cuts or layoffs. We find evidence that employment protection increases workers' bargaining power as the probability of a base wage rise is higher in firms that report firing costs as relevant obstacles to hiring. 


\section{INTRODUCTION}

During the economic and financial crisis, unemployment increased markedly in Europe, particularly for some countries. Furthermore, it has remained at an elevated level for a number of years. The severe labour market conditions have been to some extent attributed to the limited response of nominal wages and to downward wage rigidity (Schmitt-Grohé and Uribe, 2013). This paper empirically explores the behaviour of wages and the impact of wage adjustment on employment, with a focus on the role of nominal rigidities. Based on harmonised firm-level survey data from the latest wave of the Wage Dynamics Network (WDN) - a European System of Central Banks (ESCB) research network - this paper analyses wage setting behaviour as well as the employment decisions of firms in European countries during the years 2010 to 2013. Firm-level responses show their perceptions of the nature and extent of shocks, which-combined with data on wage adjustment- provides a tool to measure wage rigidities. In particular, we investigate the key determinants of wage behaviour as well as the impact of wage adjustment and demand conditions on employment at the firm level.

Rigidities could stem from several factors and the empirical literature focuses mostly on the role of institutions in wage rigidities. Holden and Wulfsberg (2008) and Anderton and Bonthuis (2015) find that downward wage rigidities reflect institutional factors such as a high degree of union coverage and employment protection, while Anderton et al. (2016) show that these institutional variables reduce the response of wages to unemployment. ${ }^{7}$ Downward wage rigidities can also be the result of employers fearing that wage cuts would reduce their employees' motivation which would lead to a fall in workers' productivity as well as increasing the quits of the most productive workers (Stiglitz, 1974, Solow, 1979, Akerlof 1982, and Du Caju et al., 2015, where the latter use data from the first wave of the WDN).

The incidence of wage freezes is often taken as an indicator of rigidities assuming that all wage freezes would be wage cuts in the absence of downward nominal wage rigidity. Results of papers based on the previous two waves of the WDN survey of European firms, suggest that wage cuts occur very rarely, even during periods of deep economic contraction and an environment of low inflation. For example, Fabiani et al. (2015) show that, out of all the firms surveyed, only $2.6 \%$ cut base wages in the period of continuing economic growth from 2002-2006, while $9.5 \%$ of firms froze wages. During the first phase of the crisis in 2009 the incidence of wage cuts increased only mildly (to $3.2 \%$ ), while the share of firms that froze wages increased markedly (to $34.5 \%$ ), indicating the presence of a significant degree of downward nominal wage rigidity in the European Union. ${ }^{8} \mathrm{~A}$ measure of the degree of

${ }^{7}$ By contrast, Knoppick and Beissinger (2009) cannot relate downward nominal wage rigidity in European countries to institutional variables.

${ }^{8}$ This result is in line with some other papers analysing the incidence of wage cuts during recessions. For example, Agell and Lundborg (2003) analysing Swedish firm survey data conclude that virtually no 
wage rigidity is proposed by Dickens et al. (2007) who use the ratio of wage freezes to the sum of freezes and wage cuts. However, we find that these measures have some drawbacks. For example, firms that respond to a fall in demand by freezing wages could be more flexible than firms that increase wages. Even in the presence of wage flexibility, wage freezes can be optimal and may occur due to specific economic circumstances. Furthermore, firms that neither cut nor freeze wages are not included in the measure. The present paper takes advantage of information on the changes in demand perceived by the firms contained in the WDN survey. We find that wages do not react symmetrically to upward and downward movements in demand. In other words, asymmetries in the marginal effects of demand provide evidence of downward nominal wage rigidity. Furthermore, collective pay agreements reduce the probability of downward wage adjustment. Given the wide range of collective bargaining coverage across countries, this result also implies significantly more downward nominal wage rigidities for countries with larger shares of employees covered by collective pay agreements.

Nominal rigidities are particularly important in a period of low inflation. The literature provides arguments for an amplifying effect of wage rigidities on unemployment during recessions as well as a mitigating effect. ${ }^{9}$ Using a small open economy model, Galì and Monacelli (2016) show recently that increasing wage flexibility could have a negative impact on welfare in a currency union and only small employment effects. Moreover, results from empirical studies are mixed on the impact of wage rigidities on employment. Babecký et al. (2012) highlight the substitutability between base wage flexibility and alternative labour cost adjustments: firms facing base wage rigidities, defined as firms freezing wages, are more likely to use alternative margins. Using microdata on Portugal, Dias et al. (2013) find that firms with more flexible base wages, which they define as firms that freeze wages, are less likely to reduce employment. This is strengthened by the availability of alternative labour cost adjustment mechanisms. By contrast, Card and Hyslop (1997) do not find any significant impact of wage flexibility on employment. Altonji and Devereux (2000) derive a measure of wage rigidity using the deviation of a notional wage change under flexible wages from the actual wage change. They do not find solid results for the impact of nominal wage rigidity on layoffs in the US. In contrast, using a similar measure of rigidity, Barwell and Schweitzer (2007) find for the UK that downward rigidities increase the probability of layoffs and Devicienti et al. (2007) find for Italy that rigidities lead to higher turnover at the firm level.

wage cuts occurred during the recession in the 1990s (only 2 out of the 153 surveyed firms cut wages).

9 For a mitigating effect see Calmfors and Johansson (2006), and Shimer (2012). By contrast, according to another strand of the literature, wages could be considered too flexible if wage cuts during recessions led to a further fall in aggregate demand and employment (Keynes, 1936, Howitt, 1986, Amendola et al., 2004). 
This paper contributes to the empirical literature on the employment impacts of downward nominal wage rigidities. Instead of using the occurrence of base wage freezes as a proxy for rigidities, we take an instrumental variables approach. In particular, the share of workers covered by a collective pay agreement is used as an instrument for base wage adjustments in an ordered probit model. The surveyed period from 2010 to 2013 is very relevant for the question we study, as a significant portion of firms faced a fall in demand and had to adjust labour costs. Estimation results show that a wage reduction significantly lowers the probability of a decrease in employment at the firm level when demand falls.

The paper is organized as follows. In Section 2, we illustrate a possible relationship between wages and employment using a simplified theoretical model framework. Section 3 describes the estimation sample. In Section 4, we estimate an ordered probit model of wage adjustment to changes in the level of demand. Section 5 aims to determine the impact of wage rigidity on employment by estimating an IV ordered probit model of employment and wage adjustments. Section 6 concludes.

\section{A SIMPLIFIED RELATIONSHIP BETWEEN WAGES AND EMPLOYMENT}

A simplified relationship between wage adjustments and employment can be derived from a Cobb-Douglas production function $Y=A K^{\alpha} L^{1-\alpha}$ with capital $K$ and labour $L$. In a profit maximizing firm, real wages equal the marginal product of labour

$$
w_{\text {real }}=(1-\alpha) A K^{\alpha} L^{-\alpha} .
$$

The real wage equals the ratio of the nominal wage $w$ and the price index $P$. Substituting $w_{\text {real }}=\frac{w}{P}$ and the production function, equation (2.1) becomes

$$
w=(1-\alpha) \frac{P Y}{L} .
$$

Let us assume that the firm's output is determined by demand for its products and that the firm can adjust wages and employment such that the above equation holds. Employment then evolves according to

$$
\Delta \ln L=\Delta \ln Y+\Delta \ln P-\Delta \ln w .
$$

If wages are completely rigid and prices remain unchanged, a fall in log output is translated entirely into a fall in log employment:

$$
\Delta \ln L=\Delta \ln Y \text {. }
$$


A wage reduction could therefore mitigate the fall in employment induced by a negative demand shock. If log wages decrease to the same extent as log output, employment remains unchanged. If the firm prefers to keep employment (and hours per worker) constant and if the level of demand for its products falls, adjustments have to take place completely by the reduction of the capital input which would reduce wages according to equation (2.1). Furthermore, for being an optimal adjustment to the firm, the real interest rate would need to increase. In this simple model, employment adjustments therefore depend on the reaction of wages and the interest rate to the development of demand. The latter is beyond the scope of this paper.

\section{DESCRIPTION OF THE ESTIMATION SAMPLE}

The analysis is based on the third wave of the WDN as the only data source. The firm survey was conducted simultaneously in 25 European Union countries ${ }^{10}$ during the second half of 2014 and beginning of 2015. It was carried out by the national central banks. All countries used a harmonised questionnaire developed in the context of the ESCB Wage Dynamics Network, a research network analysing wage and labour cost dynamics. The final sample of 15,368 firms used for estimating the empirical model (see Section 4) excludes the public sector and Ireland, as some of our variables of interest were not included in the Irish questionnaire. The harmonised questionnaire includes questions referring to general firm characteristics, perceived shocks during the 2010-2013 period and their price and wage setting strategies. Most questions were based on multiple choice from a scale of five categories, such as "strong decrease", "moderate decrease", "unchanged", "moderate increase" and "strong increase".

Three main sectors are represented in the sample: More than one third of the firms belong to the business services sector; $28 \%$ to the manufacturing sector; $22 \%$ to the trade sector. The other sectors together represent $10 \%$ of the sample (see Table 8 in the Appendix). Permanent workers constitute $90 \%$ of the total workforce and $59 \%$ of workers have tenure of more than five years. Low-skilled workers represent $43 \%$ of the workforce.

The first set of questions concerns changes in the economic environment. Firms were asked how their activity had been affected between 2010 and 2013 by a change in the level of demand for their products/services, difficulties in the access to external financing, a lower ability to pay of customers and a lower availability of supplies. A further set of questions concerns labour cost adjustments. We focus on the adjustment of employment and base wages. The "employment" variable is based on payroll composition (permanent, temporary or agency workers) and the change in the firm's number of employees. Table 1 contains summary statistics with regard to the nature of shocks and labour cost adjustments. On

${ }^{10}$ The countries of the EU except Denmark, Finland and Sweden. 
average, firms report that more than half of their employees are covered by a collective pay agreement. In most firms, the share of bonuses on the total wage bill was positive in 2013. A reduction of base wages (or piece work rates) was rare; most firms reported that base wages had moderately increased during the period. The fraction of firms that had frozen wages at least once between 2010 and 2013 is four times as high as the fraction of firms that had cut wages at least once.

\section{Table 1: Firm characteristics and shocks}

Full estimation sample Only firms with negative

\begin{tabular}{|c|c|c|}
\hline & \multicolumn{2}{|c|}{ demand shock } \\
\hline Number of observations & 15,368 & 6,758 \\
\hline \multicolumn{3}{|l|}{ Changes in the economic environment during 2010-2013 } \\
\hline \multicolumn{3}{|l|}{ Level of demand } \\
\hline Strong decrease & $13 \%$ & $30 \%$ \\
\hline Moderate decrease & $29 \%$ & $70 \%$ \\
\hline Unchanged & $20 \%$ & - \\
\hline Moderate increase & $31 \%$ & - \\
\hline Strong increase & $7 \%$ & - \\
\hline Lower access to external financing & $23 \%$ & $38 \%$ \\
\hline Customers' ability to pay decreased & $39 \%$ & $54 \%$ \\
\hline Availability of supply decreased & $14 \%$ & $21 \%$ \\
\hline \multicolumn{3}{|l|}{ (Very) relevant: Credit not available or conditions too onerous to } \\
\hline finance working capital & $29 \%$ & $35 \%$ \\
\hline finance new investment & $29 \%$ & $34 \%$ \\
\hline refinance debt & $22 \%$ & $28 \%$ \\
\hline \multicolumn{3}{|l|}{ Costs and adjustments } \\
\hline \multicolumn{3}{|l|}{ Employment during 2010-2013 } \\
\hline Strong decrease & $6 \%$ & $10 \%$ \\
\hline Moderate decrease & $21 \%$ & $33 \%$ \\
\hline Unchanged & $39 \%$ & $38 \%$ \\
\hline Moderate increase & $28 \%$ & $16 \%$ \\
\hline Strong increase & $6 \%$ & $3 \%$ \\
\hline \multicolumn{3}{|l|}{ Base wages during 2010-2013 } \\
\hline Strong decrease & $1 \%$ & $2 \%$ \\
\hline Moderate decrease & $4 \%$ & $7 \%$ \\
\hline Unchanged & $23 \%$ & $28 \%$ \\
\hline Moderate increase & $66 \%$ & $58 \%$ \\
\hline Strong increase & $5 \%$ & $5 \%$ \\
\hline Labour cost share in total costs in 2013 & $40 \%$ & $40 \%$ \\
\hline Performance related share (bonuses) in 2013 & $8 \%$ & $6 \%$ \\
\hline Share of firms paying bonuses in 2013 & $75 \%$ & $72 \%$ \\
\hline Wages were frozen in at least one year between 2010 and 2013 & $24 \%$ & $30 \%$ \\
\hline Wages were cut in at least one year between 2010 and 2013 & $5 \%$ & $7 \%$ \\
\hline $\begin{array}{l}\text { Firing costs are a (very) relevant obstacle in hiring workers with a permanent, } \\
\text { open-ended contract }\end{array}$ & $45 \%$ & $57 \%$ \\
\hline Share of workers covered by any collective pay agreement & $56 \%$ & $70 \%$ \\
\hline Share of firms with outside firm-level collective pay agreement & $42 \%$ & $53 \%$ \\
\hline
\end{tabular}


The demand development between 2010 and 2013 was heterogeneous. While $42 \%$ of firms experienced a decrease in demand, $38 \%$ indicated that demand increased. The fraction of firms reducing employment or wages is significantly higher if the firm experiences a fall in demand. Some firms use employment and wage adjustments in combination to reduce labour costs. In the presence of a negative demand shock, the tetrachoric correlation between the reduction of employment and wages is 0.4 and statistical significant at the $1 \%$ level. However, employment was reduced in $43 \%$ of the firms which experienced negative demand developments, while only $9 \%$ of these "negative demand" firms reduced base wages. We take the relatively small percentage of wage decreases as an indication of downward nominal wage rigidity.

On the contrary, there are also indications that firms significantly adjusted wages downwards when they were in severe economic difficulties. Table 2 shows substantial differences in the evolution of base wages by country. ${ }^{11}$ For example, a relatively large fraction of firms in Greece and Cyprus experienced a fall in demand, a worsening access to external financing, the inability of customers to pay, and the scarcity of supplies. Consequently, both wages and employment were decreased relatively often. Employment cuts were also frequent in other countries as the Netherlands and Slovakia (Table 3). At the same time, above $50 \%$ of firms in Bulgaria, Germany and Hungary reported that employment remained unchanged. Also at the sector level, employment reductions are more frequent than reductions of base wages (Table 4 and Table 5).

Table 2: Evolution of base wages in firms by country; full estimation sample

\begin{tabular}{lccccc}
\hline & $\begin{array}{c}\text { Strong } \\
\text { decrease }\end{array}$ & $\begin{array}{c}\text { Moderate } \\
\text { decrease }\end{array}$ & Unchanged & $\begin{array}{c}\text { Moderate } \\
\text { increase }\end{array}$ & $\begin{array}{c}\text { Strong } \\
\text { increase }\end{array}$ \\
\hline Austria & $0.1 \%$ & $0.8 \%$ & $6.2 \%$ & $72.6 \%$ & $20.2 \%$ \\
Belgium & $0.2 \%$ & $0.5 \%$ & $8.8 \%$ & $82.2 \%$ & $8.3 \%$ \\
Bulgaria & $1.4 \%$ & $14.2 \%$ & $22.2 \%$ & $59.2 \%$ & $3.0 \%$ \\
Cyprus & $13.9 \%$ & $46.8 \%$ & $17.8 \%$ & $21.5 \%$ & $0.0 \%$ \\
Czech Republic & $0.4 \%$ & $9.0 \%$ & $39.7 \%$ & $47.7 \%$ & $3.2 \%$ \\
Germany & $0.4 \%$ & $2.6 \%$ & $15.8 \%$ & $72.8 \%$ & $8.5 \%$ \\
Estonia & $1.8 \%$ & $2.7 \%$ & $13.3 \%$ & $70.5 \%$ & $11.7 \%$ \\
Spain & $2.2 \%$ & $4.9 \%$ & $39.3 \%$ & $52.3 \%$ & $1.3 \%$ \\
France & $0.3 \%$ & $2.0 \%$ & $15.7 \%$ & $74.7 \%$ & $7.2 \%$ \\
Greece & $30.8 \%$ & $34.5 \%$ & $22.2 \%$ & $12.5 \%$ & $0.0 \%$ \\
Croatia & $5.4 \%$ & $18.1 \%$ & $38.1 \%$ & $37.0 \%$ & $1.4 \%$ \\
\hline Hungary & $0.2 \%$ & $3.9 \%$ & $47.8 \%$ & $46.4 \%$ & $1.6 \%$ \\
\hline Italy & $0.0 \%$ & $5.7 \%$ & $15.9 \%$ & $70.5 \%$ & $7.9 \%$ \\
\hline Lithuania & $2.8 \%$ & $5.4 \%$ & $21.6 \%$ & $64.0 \%$ & $6.1 \%$ \\
\hline
\end{tabular}

${ }^{11}$ Country-specific figures shown here refer to our estimation sample and may differ from figures of the WDN survey country reports which can be found on the WDN website (http://www.ecb.europa.eu/pub/economic-research/researchnetworks/html/researcher_wdn.en.html). 


\begin{tabular}{lccccc}
\hline Luxembourg & $0.4 \%$ & $2.4 \%$ & $16.4 \%$ & $63.3 \%$ & $17.5 \%$ \\
\hline Latvia & $3.0 \%$ & $4.3 \%$ & $25.8 \%$ & $56.2 \%$ & $10.7 \%$ \\
Malta & $0.0 \%$ & $1.1 \%$ & $13.3 \%$ & $79.5 \%$ & $6.2 \%$ \\
\hline Netherlands & $1.0 \%$ & $7.9 \%$ & $38.6 \%$ & $48.0 \%$ & $4.6 \%$ \\
Poland & $1.1 \%$ & $5.8 \%$ & $23.5 \%$ & $65.2 \%$ & $4.4 \%$ \\
\hline Portugal & $1.7 \%$ & $7.5 \%$ & $47.7 \%$ & $42.5 \%$ & $0.7 \%$ \\
Romania & $0.7 \%$ & $4.4 \%$ & $18.6 \%$ & $74.2 \%$ & $2.1 \%$ \\
Slovenia & $2.2 \%$ & $14.4 \%$ & $47.4 \%$ & $35.4 \%$ & $0.6 \%$ \\
Slovakia & $0.4 \%$ & $4.3 \%$ & $18.0 \%$ & $75.0 \%$ & $2.3 \%$ \\
\hline United Kingdom & $0.0 \%$ & $2.1 \%$ & $11.5 \%$ & $81.9 \%$ & $4.5 \%$ \\
Total & $0.9 \%$ & $4.4 \%$ & $23.1 \%$ & $66.1 \%$ & $5.5 \%$ \\
\hline Note: Figures are employment weighted. & & & & \\
\hline
\end{tabular}

Table 3: Evolution of employment in firms by country; full estimation sample

\begin{tabular}{|c|c|c|c|c|c|}
\hline & $\begin{array}{c}\text { Strong } \\
\text { decrease }\end{array}$ & $\begin{array}{c}\text { Moderate } \\
\text { decrease }\end{array}$ & Unchanged & $\begin{array}{l}\text { Moderate } \\
\text { increase }\end{array}$ & $\begin{array}{c}\text { Strong } \\
\text { increase }\end{array}$ \\
\hline Austria & $0.3 \%$ & $18.7 \%$ & $23.3 \%$ & $40.0 \%$ & $17.7 \%$ \\
\hline Belgium & $3.9 \%$ & $25.5 \%$ & $25.5 \%$ & $31.4 \%$ & $13.7 \%$ \\
\hline Bulgaria & $6.6 \%$ & $18.7 \%$ & $57.2 \%$ & $16.8 \%$ & $0.7 \%$ \\
\hline Cyprus & $12.1 \%$ & $48.6 \%$ & $21.9 \%$ & $17.4 \%$ & $0.0 \%$ \\
\hline Czech Republic & $4.3 \%$ & $24.0 \%$ & $27.9 \%$ & $37.7 \%$ & $6.1 \%$ \\
\hline Germany & $1.3 \%$ & $8.2 \%$ & $61.5 \%$ & $25.5 \%$ & $3.5 \%$ \\
\hline Estonia & $1.5 \%$ & $9.7 \%$ & $42.6 \%$ & $41.1 \%$ & $5.1 \%$ \\
\hline Spain & $6.3 \%$ & $24.6 \%$ & $35.0 \%$ & $29.0 \%$ & $5.0 \%$ \\
\hline France & $7.4 \%$ & $23.5 \%$ & $36.3 \%$ & $24.1 \%$ & $8.7 \%$ \\
\hline Greece & $27.0 \%$ & $30.9 \%$ & $13.2 \%$ & $16.2 \%$ & $12.6 \%$ \\
\hline Croatia & $9.1 \%$ & $32.8 \%$ & $23.5 \%$ & $26.4 \%$ & $8.2 \%$ \\
\hline Hungary & $2.0 \%$ & $13.5 \%$ & $70.3 \%$ & $13.0 \%$ & $1.3 \%$ \\
\hline Italy & $17.2 \%$ & $23.0 \%$ & $24.6 \%$ & $32.0 \%$ & $3.2 \%$ \\
\hline Lithuania & $3.9 \%$ & $16.9 \%$ & $43.6 \%$ & $30.2 \%$ & $5.3 \%$ \\
\hline Luxembourg & $5.2 \%$ & $22.6 \%$ & $27.7 \%$ & $35.9 \%$ & $8.6 \%$ \\
\hline Latvia & $7.0 \%$ & $12.5 \%$ & $32.7 \%$ & $31.8 \%$ & $16.0 \%$ \\
\hline Malta & $1.9 \%$ & $19.3 \%$ & $25.1 \%$ & $45.9 \%$ & $7.8 \%$ \\
\hline Netherlands & $10.6 \%$ & $39.1 \%$ & $36.7 \%$ & $11.2 \%$ & $2.5 \%$ \\
\hline Poland & $2.4 \%$ & $19.5 \%$ & $37.0 \%$ & $37.2 \%$ & $3.9 \%$ \\
\hline Portugal & $6.4 \%$ & $22.7 \%$ & $37.3 \%$ & $30.0 \%$ & $3.6 \%$ \\
\hline Romania & $4.4 \%$ & $23.1 \%$ & $23.0 \%$ & $43.5 \%$ & $6.0 \%$ \\
\hline Slovenia & $5.7 \%$ & $29.8 \%$ & $32.5 \%$ & $28.8 \%$ & $3.2 \%$ \\
\hline Slovakia & $10.0 \%$ & $31.7 \%$ & $26.3 \%$ & $27.7 \%$ & $4.2 \%$ \\
\hline United Kingdom & $3.2 \%$ & $15.6 \%$ & $25.5 \%$ & $41.2 \%$ & $14.4 \%$ \\
\hline Total & $5.7 \%$ & $20.7 \%$ & $38.8 \%$ & $28.4 \%$ & $6.4 \%$ \\
\hline
\end{tabular}


Table 4: Evolution of base wages in firms by sector; full estimation sample

\begin{tabular}{lccccc}
\hline & $\begin{array}{c}\text { Strong } \\
\text { decrease }\end{array}$ & $\begin{array}{c}\text { Moderate } \\
\text { decrease }\end{array}$ & Unchanged & $\begin{array}{c}\text { Moderate } \\
\text { increase }\end{array}$ & $\begin{array}{c}\text { Strong } \\
\text { increase }\end{array}$ \\
\hline Manufacturing & $0.5 \%$ & $4.1 \%$ & $20.7 \%$ & $70.2 \%$ & $4.4 \%$ \\
Electricity, gas, water & $0.3 \%$ & $8.5 \%$ & $13.0 \%$ & $76.4 \%$ & $1.8 \%$ \\
Construction & $2.4 \%$ & $7.3 \%$ & $26.1 \%$ & $59.5 \%$ & $4.7 \%$ \\
Trade & $1.0 \%$ & $3.4 \%$ & $26.5 \%$ & $64.9 \%$ & $4.2 \%$ \\
Business services & $0.9 \%$ & $4.5 \%$ & $22.9 \%$ & $64.7 \%$ & $7.0 \%$ \\
Financial intermediation & $0.0 \%$ & $4.9 \%$ & $22.1 \%$ & $71.3 \%$ & $1.8 \%$ \\
Arts & $0.0 \%$ & $2.1 \%$ & $15.1 \%$ & $56.4 \%$ & $26.5 \%$ \\
Notal & $0.9 \%$ & $4.4 \%$ & $23.1 \%$ & $66.1 \%$ & $5.5 \%$ \\
\hline
\end{tabular}

Table 5: Evolution of employment in firms by sector; full estimation sample

\begin{tabular}{lccccc}
\hline & $\begin{array}{c}\text { Strong } \\
\text { decrease }\end{array}$ & $\begin{array}{c}\text { Moderate } \\
\text { decrease }\end{array}$ & Unchanged & $\begin{array}{c}\text { Moderate } \\
\text { increase }\end{array}$ & $\begin{array}{c}\text { Strong } \\
\text { increase }\end{array}$ \\
\hline Manufacturing & $6.3 \%$ & $22.3 \%$ & $37.7 \%$ & $28.6 \%$ & $5.1 \%$ \\
Electricity, gas, water & $2.4 \%$ & $30.6 \%$ & $33.6 \%$ & $28.2 \%$ & $5.1 \%$ \\
Construction & $7.5 \%$ & $24.3 \%$ & $41.1 \%$ & $23.9 \%$ & $3.2 \%$ \\
Trade & $4.6 \%$ & $19.9 \%$ & $40.1 \%$ & $30.1 \%$ & $5.3 \%$ \\
Business services & $5.7 \%$ & $19.0 \%$ & $38.4 \%$ & $28.7 \%$ & $8.2 \%$ \\
Arts & $8.4 \%$ & $21.6 \%$ & $43.8 \%$ & $13.2 \%$ & $13.0 \%$ \\
Total & $2.7 \%$ & $30.2 \%$ & $29.2 \%$ & $36.9 \%$ & $1.0 \%$ \\
Note: Figures are employment weighted. & $5.7 \%$ & $20.7 \%$ & $38.8 \%$ & $28.4 \%$ & $6.4 \%$ \\
\hline
\end{tabular}

In our analysis below, collective bargaining agreements play a key role in the results, therefore we analyse the data more thoroughly for this variable also at the country level. First, the share of workers covered by a collective pay agreement in the euro area countries (average $70 \%$ ) is much higher than for the non-euro countries $(21 \%) .{ }^{12}$ Several countries are significantly above the euro area average, such as: Belgium (95\%); Spain (97\%); France (94\%); Italy (99\%); the Netherlands (90\%); Austria (75\%); Slovenia $(80 \%)$, while Portugal and Greece also have high shares of approximately $60 \%$. With the exception of the Netherlands, these high shares are driven by collective bargaining agreements outside the firm (i.e., national or sectoral, rather than more decentralised firm-level agreements). By contrast, there are a number of euro area countries with collective bargaining coverage substantially below the euro average, including several countries where the share of workers covered by collective bargaining agreements is below 25\%, namely: Estonia (8\%); Latvia (22\%); and Lithuania (16\%). For the non-euro area EU countries, the UK and Poland have

${ }^{12}$ Reported shares are employment weighted averages of the full estimation sample. 
relatively low proportions of workers covered by collective pay agreements, while Romania (73\%) and Croatia (47\%) have relatively high bargaining coverage.

\section{EVIDENCE OF DOWNWARD NOMINAL WAGE RIGIDITY}

We explore the empirical wage response to changes in the level of demand by estimation of the following ordered probit model of wage adjustments:

$$
W_{i}^{*}=\gamma Z_{i}+X_{i}^{\prime} \beta_{1}+\varepsilon_{i 1}
$$

where $W_{i}^{*}$ is a latent variable. Further $W_{i}=k$ if $d_{k-1}<W_{i}^{*} \leq d_{k}$, with $k=1, \ldots 5 ; d_{k}$ are estimated threshold parameters, with $d_{0}=-\infty$ and $d_{5}=\infty$. There are five different outcomes of $W_{i}$ : strong decrease, moderate decrease, unchanged, moderate increase and strong increase. We use nominal base wages here. Data are qualitative, which does not enable us to compute real wages. The price indices are captured by the sector and country dummies.

Wage adjustments depend on the wage bargaining process. ${ }^{13}$ Therefore, the share of workers covered by a collective pay agreement, denoted by $Z_{i}$, is included in the wage equation. The vector of covariates $X_{i}$ comprises among other things the development of demand (all five categories). Estimation results (Table 6) show that the level of demand significantly determines wages. Furthermore, the wage response is larger when the demand shock is strong. The share of workers covered by any collective pay agreement is significant at the $1 \%$ level. It increases the probability of a base wage raise and lowers the probability of unchanged wages or a decrease in wages. This provides evidence in support of an influence of the wage bargaining process on the degree of downward nominal wage rigidity. Given the wide range of collective bargaining coverage across countries shown in Section 3, this result implies significantly more downward nominal wage rigidities for countries with much higher shares of employees covered by collective pay agreements. The results also contain evidence in favour of asymmetric demand elasticities for wages and thereby indicate downward nominal wage rigidity: ${ }^{14}$ the rise in the probability of a downward base wage response to a decrease in demand is significantly smaller than the rise in the probability of upward wage responses to an increase in demand. ${ }^{15}$ Furthermore, a strong and moderate fall in demand significantly increases the probability that base wages will remain unchanged,

\footnotetext{
${ }^{13}$ For a theoretical analysis of the influence of the bargaining process on wage flexibility see Hall and Milgrom (2008).

${ }^{14}$ These asymmetric marginal effects remain de facto unchanged regardless of including the collective pay agreement variable in the equation. The fear of employers that wage cuts would reduce their employees' motivation is one possible explanation for this finding.

${ }^{15}$ We conducted z-tests to compare the marginal effects.
} 
whereas one might expect these decreases in demand to actually reduce wages. Hence, this is further evidence of downward nominal wage rigidity, as the distribution of changes in wages starts to bunch around unchanged base wages when demand falls. By contrast, a moderate or strong increase in demand is associated with a lower probability of base wages staying unchanged. ${ }^{16}$ In another specification, we include the persistence of the strong demand shock ${ }^{17}$ and also find evidence of downward nominal wage rigidity. The size of the wage reaction not only increases with the strength of the demand shock but also with its persistence.

Table 6: Ordered probit estimation of wage responses to a change in the level of demand

Marginal effects on the probability of observing the outcome

\begin{tabular}{|c|c|c|c|c|c|}
\hline VARIABLES & $\begin{array}{c}\text { (1) } \\
\text { base wages } \\
\text { strong decrease }\end{array}$ & $\begin{array}{c}(2) \\
\text { base wages } \\
\text { moderate decrease }\end{array}$ & $\begin{array}{c}\text { (3) } \\
\text { base wages } \\
\text { unchanged }\end{array}$ & $\begin{array}{c}\text { (4) } \\
\text { base wages } \\
\text { moderate increase }\end{array}$ & $\begin{array}{c}(5) \\
\text { base wages } \\
\text { strong increase }\end{array}$ \\
\hline Collective pay agreement ${ }^{\mathrm{a}}$ & $\begin{array}{c}-0.004 * * * \\
(0.001)\end{array}$ & $\begin{array}{c}-0.012 * * * \\
(0.002)\end{array}$ & $\begin{array}{c}-0.027 * * * \\
(0.006)\end{array}$ & $\begin{array}{c}0.033 * * * \\
(0.007)\end{array}$ & $\begin{array}{c}0.010 * * * \\
(0.002)\end{array}$ \\
\hline \multicolumn{6}{|l|}{ Demand } \\
\hline Strong decrease & $\begin{array}{c}0.015^{* * * *} \\
(0.002)\end{array}$ & $\begin{array}{c}0.037 * * * \\
(0.004)\end{array}$ & $\begin{array}{c}0.071 * * * \\
(0.007)\end{array}$ & $\begin{array}{c}-0.106^{* * *} \\
(0.011)\end{array}$ & $\begin{array}{c}-0.017 * * * \\
(0.002)\end{array}$ \\
\hline Moderate decrease & $\begin{array}{c}0.005^{* * *} * \\
(0.001)\end{array}$ & $\begin{array}{c}0.013 * * * \\
(0.003)\end{array}$ & $\begin{array}{c}0.030 * * * \\
(0.006)\end{array}$ & $\begin{array}{c}-0.040^{* * *} * \\
(0.008)\end{array}$ & $\begin{array}{c}-0.008 * * * \\
(0.002)\end{array}$ \\
\hline Unchanged (reference) & & & & & \\
\hline Moderate increase & $\begin{array}{c}-0.007^{* * * *} \\
(0.001)\end{array}$ & $\begin{array}{c}-0.025^{* * *} * \\
(0.002)\end{array}$ & $\begin{array}{c}-0.077 * * * \\
(0.006)\end{array}$ & $\begin{array}{c}0.080 * * * \\
(0.007)\end{array}$ & $\begin{array}{c}0.029 * * * \\
(0.002)\end{array}$ \\
\hline Strong increase & $\begin{array}{c}-0.010^{* * *} \\
(0.001)\end{array}$ & $\begin{array}{c}-0.037 * * * \\
(0.003)\end{array}$ & $\begin{array}{c}-0.133 * * * \\
(0.011)\end{array}$ & $\begin{array}{c}0.120 * * * \\
(0.008)\end{array}$ & $\begin{array}{c}0.060 * * * \\
(0.007)\end{array}$ \\
\hline Negative shocks: & & & & & \\
\hline Finance & $\begin{array}{c}0.006 * * * \\
(0.001)\end{array}$ & $\begin{array}{c}0.015 * * * \\
(0.003)\end{array}$ & $\begin{array}{c}0.032 * * * \\
(0.005)\end{array}$ & $\begin{array}{c}-0.041^{* * *} * \\
(0.007)\end{array}$ & $\begin{array}{c}-0.011 \text { *** } \\
(0.002)\end{array}$ \\
\hline Customers & $\begin{array}{c}0.000 \\
(0.001)\end{array}$ & $\begin{array}{c}0.001 \\
(0.002)\end{array}$ & $\begin{array}{c}0.002 \\
(0.005)\end{array}$ & $\begin{array}{l}-0.003 \\
(0.006)\end{array}$ & $\begin{array}{l}-0.001 \\
(0.002)\end{array}$ \\
\hline Supplies & $\begin{array}{l}0.002^{*} \\
(0.001)\end{array}$ & $\begin{array}{l}0.005^{*} \\
(0.003)\end{array}$ & $\begin{array}{l}0.011 * \\
(0.006)\end{array}$ & $\begin{array}{l}-0.014 * \\
(0.008)\end{array}$ & $\begin{array}{c}-0.004 * \\
(0.002)\end{array}$ \\
\hline $\begin{array}{l}\text { Observations } \\
\text { p-value } \\
\text { Pseudo R-squared }\end{array}$ & $\begin{array}{c}15,368 \\
0.000 \\
0.110\end{array}$ & & & & \\
\hline
\end{tabular}

Note: Firm size, sector and country dummies as well as workforce characteristics (share of workers: permanent contract, more than five years of tenure, higher skilled, manual) included. Marginal effect for indicator variables is the discrete change from the base level.

\footnotetext{
${ }^{16}$ We obtain similar results for the subsample of firms with unchanged prices in domestic and foreign markets.

17 This yields nine categories of demand development, as the strong positive or negative shock is further subdivided into a "transitory", "only partly persistent", and "long-lasting" positive or negative shock.
} 
While the estimation results show evidence of downward nominal wage rigidity, they also show that in cases of strong economic difficulties wages may not be rigid downwards. The estimated downward response of wages in the case of a negative demand (or finance) shock is non-negligible. We therefore run as a robustness check the wage regression without Greece and Cyprus, where a high percentage of firms has lowered wages. The marginal effects change only slightly.

\section{WAGE ADJUSTMENTS AND EMPLOYMENT}

In the following, we explore the impact of wage responses to a negative demand shock on the development of employment. In particular we analyse how employment evolves when a firm experiences a fall in demand and is constrained by downward nominal wage rigidity. The hypothesis is that when the firm cannot lower wages it reduces employment. The ordered probit model of employment adjustments is given by

$$
L_{i}^{*}=\alpha W_{i}+X_{i}^{\prime} \beta_{2}+\varepsilon_{i 2},
$$

where $L_{i}^{*}$ is a latent variable. Further $L_{i}=k, c_{k-1}<L_{i}^{*} \leq c_{k}$, whereby $c_{k}$ are estimated threshold parameters with $c_{0}=-\infty$ and $c_{5}=\infty$. We are especially interested in the parameter $\alpha$ which captures the effect of wage adjustments on employment. In contrast to the theoretical model presented in Section 2, prices are not explicitly included. The price index is assumed country and sector-specific and is captured by the corresponding dummies.

Firms can adjust both employment and wages in response to changing economic conditions. To take the possible endogeneity of wages in the employment equation into account, we use an instrumental variable approach with employment equation (5.1) and wage equation (4.1). The error terms are jointly normally distributed:

$$
\left(\begin{array}{l}
\varepsilon_{i 1} \\
\varepsilon_{i 2}
\end{array}\right) \sim N\left[\left(\begin{array}{l}
0 \\
0
\end{array}\right),\left(\begin{array}{ll}
1 & \rho \\
\rho & 1
\end{array}\right)\right] .
$$

With wages being endogenous in the employment equation, the error terms are correlated $(\rho \neq 0)$. The share of workers covered by a collective pay agreement, $Z_{i}$, serves as an instrumental variable for wage adjustments. We presume that collective bargaining has no direct effect on employment adjustment in Europe as it seldom covers severance pay and notice periods different from legislation (Venn, 2009). The view that bargaining is over wages and employers take the wage as given when "choosing the employment levels" is a "standard (and realistic) characterization of collective bargaining" according to Boeri and van Ours (2013, p. 71). Moreover, a positive impact of unionisation on employment is not supported by empirical evidence in the literature (see e.g. DiNardo and Lee, 2004), while a 
negative effect (found e.g. by Sojourner et al., 2015) can be interpreted as an indirect one through wages.

\subsection{WAGE RIGIDITIES AND EMPLOYMENT ADJUSTMENTS FOLLOWING A DEMAND SHOCK}

Estimation results are presented in Table 7. As we consider only firms that experienced a fall in demand, the ordinal demand variable is replaced by a dummy equal to one if the negative demand shock was strong and equal to zero if demand decreased only moderately.

Evidence of downward nominal wage rigidity is also present in the IV ordered probit estimation (Table 7, top panel, wage equations) with collective bargaining agreements reducing the probability of downward wage adjustment. The significant correlation of the error terms (see $\rho$, bottom of Table 7) confirms that wages are endogenous in the employment equation and that the IV approach is adequate. Wage adjustments have a significant effect on employment within the firm (Table 7, bottom panel employment equations). The probability that employment falls or remains unchanged is significantly lower when wages decrease compared to the reference category of unchanged base wages. The probability of an increase in employment is accordingly raised. If wages increase, the probability of a decrease in employment is higher than under unchanged wages.

\section{Table 7: IV ordered probit estimation; only firms with negative demand shock}

Marginal effects on the probability of observing the outcome

\begin{tabular}{|c|c|c|c|c|c|}
\hline $\begin{array}{l}\text { Wage equation } \\
\text { VARIABLES }\end{array}$ & $\begin{array}{c}\text { (1) } \\
\text { base wages } \\
\text { strong decrease }\end{array}$ & $\begin{array}{c}\text { (2) } \\
\text { base wages } \\
\text { moderate decrease }\end{array}$ & $\begin{array}{c}\text { (3) } \\
\text { base wages } \\
\text { unchanged }\end{array}$ & $\begin{array}{c}(4) \\
\text { base wages } \\
\text { moderate increase }\end{array}$ & $\begin{array}{c}\text { (5) } \\
\text { base wages } \\
\text { strong increase }\end{array}$ \\
\hline Collective pay agreement ${ }^{\mathrm{a}}$ & $\begin{array}{c}-0.007 * * * \\
(0.002)\end{array}$ & $\begin{array}{c}-0.015 * * * \\
(0.004)\end{array}$ & $\begin{array}{c}-0.017 * * * \\
(0.005)\end{array}$ & $\begin{array}{c}0.032 * * * \\
(0.009)\end{array}$ & $\begin{array}{c}0.007 * * * \\
(0.002)\end{array}$ \\
\hline Strong demand shock & $\begin{array}{c}0.012 * * * \\
(0.002)\end{array}$ & $\begin{array}{c}0.027 * * * \\
(0.004)\end{array}$ & $\begin{array}{c}0.028 * * * \\
(0.004)\end{array}$ & $\begin{array}{c}-0.056^{* * *} \\
(0.009)\end{array}$ & $\begin{array}{c}-0.012 * * * \\
(0.002)\end{array}$ \\
\hline \multicolumn{6}{|l|}{ Negative shocks: } \\
\hline Finance & $\begin{array}{c}0.008^{* * * *} \\
(0.002)\end{array}$ & $\begin{array}{c}0.017 \text { *** } \\
(0.005)\end{array}$ & $\begin{array}{c}0.019 * * * \\
(0.005)\end{array}$ & $\begin{array}{c}-0.036^{* * * *} \\
(0.010)\end{array}$ & $\begin{array}{c}-0.008^{* * *} * \\
(0.002)\end{array}$ \\
\hline Customers & $\begin{array}{c}0.003 \\
(0.002)\end{array}$ & $\begin{array}{c}0.006 \\
(0.004)\end{array}$ & $\begin{array}{c}0.007 \\
(0.005)\end{array}$ & $\begin{array}{l}-0.012 \\
(0.009)\end{array}$ & $\begin{array}{l}-0.003 \\
(0.002)\end{array}$ \\
\hline Supplies & $\begin{array}{c}0.002 \\
(0.002)\end{array}$ & $\begin{array}{c}0.005 \\
(0.005)\end{array}$ & $\begin{array}{c}0.005 \\
(0.005)\end{array}$ & $\begin{array}{l}-0.010 \\
(0.010)\end{array}$ & $\begin{array}{l}-0.002 \\
(0.002)\end{array}$ \\
\hline Foreign ownership & $\begin{array}{c}-0.004^{*} \\
(0.002)\end{array}$ & $\begin{array}{l}-0.010^{*} \\
(0.005)\end{array}$ & $\begin{array}{c}-0.012 * \\
(0.007)\end{array}$ & $\begin{array}{l}0.021 * \\
(0.012)\end{array}$ & $\begin{array}{l}0.005^{*} \\
(0.003)\end{array}$ \\
\hline Bonuses & $\begin{array}{c}-0.008 * * * \\
(0.002)\end{array}$ & $\begin{array}{c}-0.016 * * * \\
(0.004)\end{array}$ & $\begin{array}{c}-0.018 * * * \\
(0.005)\end{array}$ & $\begin{array}{c}0.034 * * * \\
(0.009)\end{array}$ & $\begin{array}{c}0.008 * * * \\
(0.002)\end{array}$ \\
\hline Labour cost share & $\begin{array}{c}-0.004 \\
(0.004)\end{array}$ & $\begin{array}{l}-0.010 \\
(0.010)\end{array}$ & $\begin{array}{c}-0.011 \\
(0.011)\end{array}$ & $\begin{array}{c}0.020 \\
(0.020)\end{array}$ & $\begin{array}{c}0.005 \\
(0.005)\end{array}$ \\
\hline Firing costs & $\begin{array}{c}-0.007 * * * * \\
(0.002)\end{array}$ & $\begin{array}{c}-0.014 * * * \\
(0.004)\end{array}$ & $\begin{array}{c}-0.016 * * * \\
(0.004)\end{array}$ & $\begin{array}{c}0.030 * * * \\
(0.008)\end{array}$ & $\begin{array}{c}0.007 * * * \\
(0.002)\end{array}$ \\
\hline Credit constraint ${ }^{\mathrm{b}}$ & $\begin{array}{c}0.008 * * * \\
(0.002)\end{array}$ & $\begin{array}{c}0.018 * * * \\
(0.004)\end{array}$ & $\begin{array}{c}0.021 * * * \\
(0.005)\end{array}$ & $\begin{array}{c}-0.039 * * * \\
(0.009)\end{array}$ & $\begin{array}{c}-0.008 * * * \\
(0.002)\end{array}$ \\
\hline
\end{tabular}




\begin{tabular}{|c|c|c|c|c|c|}
\hline $\begin{array}{l}\text { Employment equation } \\
\text { VARIABLES }\end{array}$ & $\begin{array}{c}(1) \\
\text { employment } \\
\text { strong decrease }\end{array}$ & $\begin{array}{c}\text { (2) } \\
\text { employment } \\
\text { moderate decrease }\end{array}$ & $\begin{array}{c}\text { (3) } \\
\text { employment } \\
\text { unchanged }\end{array}$ & $\begin{array}{c}(4) \\
\text { employment } \\
\text { moderate increase }\end{array}$ & $\begin{array}{c}\text { (5) } \\
\text { employment } \\
\text { strong increase }\end{array}$ \\
\hline \multicolumn{6}{|l|}{ Base wages: } \\
\hline Strong decrease & $\begin{array}{c}-0.091 * * * \\
(0.014)\end{array}$ & $\begin{array}{c}-0.126^{* * *} \\
(0.014)\end{array}$ & $\begin{array}{c}-0.076^{* * * *} \\
(0.029)\end{array}$ & $\begin{array}{c}0.097 * * * \\
(0.016)\end{array}$ & $\begin{array}{c}0.196^{* * * *} \\
(0.069)\end{array}$ \\
\hline Moderate decrease & $\begin{array}{c}-0.072^{* * * *} \\
(0.010)\end{array}$ & $\begin{array}{c}-0.088^{* * *} \\
(0.007)\end{array}$ & $\begin{array}{c}-0.037 * * * \\
(0.013)\end{array}$ & $\begin{array}{c}0.080^{* * * *} \\
(0.007)\end{array}$ & $\begin{array}{c}0.118 * * * \\
(0.034)\end{array}$ \\
\hline \multicolumn{6}{|l|}{ Unchanged (reference) } \\
\hline Moderate increase & $\begin{array}{c}0.190 * * * \\
(0.031)\end{array}$ & $\begin{array}{c}0.078 * * * \\
(0.005)\end{array}$ & $\begin{array}{c}-0.066 * * * \\
(0.003)\end{array}$ & $\begin{array}{c}-0.128 * * * \\
(0.009)\end{array}$ & $\begin{array}{c}-0.073 * * * \\
(0.018)\end{array}$ \\
\hline Strong increase & $\begin{array}{c}0.587 * * * \\
(0.065)\end{array}$ & $\begin{array}{c}-0.021 \\
(0.033)\end{array}$ & $\begin{array}{c}-0.249 * * * \\
(0.009)\end{array}$ & $\begin{array}{c}-0.222 * * * \\
(0.011)\end{array}$ & $\begin{array}{c}-0.095^{* * * *} \\
(0.021)\end{array}$ \\
\hline Strong demand shock & $\begin{array}{c}0.119 * * * \\
(0.008)\end{array}$ & $\begin{array}{c}0.044 * * * \\
(0.009)\end{array}$ & $\begin{array}{c}-0.039 * * * \\
(0.008)\end{array}$ & $\begin{array}{c}-0.076 * * * \\
(0.009)\end{array}$ & $\begin{array}{c}-0.047 * * * \\
(0.007)\end{array}$ \\
\hline \multicolumn{6}{|l|}{ Negative shocks: } \\
\hline Finance & $\begin{array}{c}0.027 * * * \\
(0.008)\end{array}$ & $\begin{array}{c}0.012 * * * \\
(0.004)\end{array}$ & $\begin{array}{c}-0.008 * * * \\
(0.002)\end{array}$ & $\begin{array}{c}-0.018 * * * \\
(0.005)\end{array}$ & $\begin{array}{c}-0.013 * * * \\
(0.004)\end{array}$ \\
\hline Customers & $\begin{array}{l}-0.001 \\
(0.007)\end{array}$ & $\begin{array}{l}-0.000 \\
(0.003)\end{array}$ & $\begin{array}{c}0.000 \\
(0.002)\end{array}$ & $\begin{array}{c}0.000 \\
(0.005)\end{array}$ & $\begin{array}{c}0.000 \\
(0.003)\end{array}$ \\
\hline Supplies & $\begin{array}{l}0.015^{*} \\
(0.008)\end{array}$ & $\begin{array}{l}0.006^{*} \\
(0.004)\end{array}$ & $\begin{array}{l}-0.004^{*} \\
(0.002)\end{array}$ & $\begin{array}{l}-0.010^{*} \\
(0.005)\end{array}$ & $\begin{array}{l}-0.007^{*} \\
(0.004)\end{array}$ \\
\hline Foreign ownership & $\begin{array}{l}-0.003 \\
(0.010)\end{array}$ & $\begin{array}{l}-0.001 \\
(0.004)\end{array}$ & $\begin{array}{c}0.001 \\
(0.003)\end{array}$ & $\begin{array}{c}0.002 \\
(0.007)\end{array}$ & $\begin{array}{c}0.002 \\
(0.005)\end{array}$ \\
\hline Bonuses & $\begin{array}{c}-0.025^{* * *} \\
(0.007)\end{array}$ & $\begin{array}{c}-0.011^{* * * *} \\
(0.003)\end{array}$ & $\begin{array}{c}0.007 * * * \\
(0.002)\end{array}$ & $\begin{array}{c}0.017 * * * \\
(0.005)\end{array}$ & $\begin{array}{c}0.012 * * * * \\
(0.004)\end{array}$ \\
\hline Labour cost share & $\begin{array}{l}0.031^{*} \\
(0.016)\end{array}$ & $\begin{array}{l}0.014^{*} \\
(0.008)\end{array}$ & $\begin{array}{l}-0.008^{*} \\
(0.005)\end{array}$ & $\begin{array}{l}-0.021^{*} \\
(0.012)\end{array}$ & $\begin{array}{l}-0.015^{*} \\
(0.008)\end{array}$ \\
\hline Firing costs & $\begin{array}{l}-0.010 \\
(0.007)\end{array}$ & $\begin{array}{l}-0.004 \\
(0.003)\end{array}$ & $\begin{array}{c}0.003 \\
(0.002)\end{array}$ & $\begin{array}{c}0.007 \\
(0.004)\end{array}$ & $\begin{array}{c}0.005 \\
(0.003)\end{array}$ \\
\hline Credit constraint ${ }^{\mathrm{b}}$ & $\begin{array}{c}0.037 * * * \\
(0.008)\end{array}$ & $\begin{array}{c}0.016^{* * *} * \\
(0.004)\end{array}$ & $\begin{array}{c}-0.011 * * * \\
(0.003)\end{array}$ & $\begin{array}{c}-0.025 * * * \\
(0.005)\end{array}$ & $\begin{array}{c}-0.017 * * * \\
(0.004)\end{array}$ \\
\hline Observations & 6,758 & & & & \\
\hline p-value & 0.000 & & & & \\
\hline rho & 0.783 & & & & \\
\hline
\end{tabular}

Note: Firm size, sector and country dummies as well as workforce characteristics (share of workers: permanent contract, more than five years of tenure, higher skilled, manual) included. The IV ordered probit model was estimated using the Stata command cmp written by Roodman (2011). Marginal effect for indicator variables is the discrete change from the base level.

\subsection{FURTHER DETERMINANTS OF WAGE AND EMPLOYMENT ADJUSTMENTS}

The IV ordered probit estimation results (Table 7) show that wages and employment depend on similar economic circumstances. Both are more likely to decrease if the fall in demand is strong. With regards to wages, also the probability of unchanged wages is increased.

A decrease in the availability of supplies from the firm's usual suppliers, a fall in the customers' ability to pay and meet contractual terms and lower access to external financing raises the probability of lower employment and wages. As in the case of a negative demand 
shock, also the probability of unchanged wages is increased. The customers shock is not statistically significant and the supply shock is not statistically significant for wages.

We capture flexible wage components by a dummy variable equal to one if the firm uses bonuses. We find that firms which use flexible wage components are more likely to increase base wages and less likely to reduce employment. This suggests that some firms tend to use bonuses as a buffer to avoid base wage cuts or layoffs.

The probability of a base wage rise is higher in firms that report firing costs as relevant obstacles in hiring. The firing cost variable captures the strictness of employment protection. Its positive impact on wages works through the strengthening of workers' bargaining power. We do not find a significant effect of firing costs on employment.

If the firm is credit constrained ${ }^{18}$, the probability of wage reductions and unchanged wages is higher. Furthermore, the probability of employment reduction is increased.

\subsection{ROBUSTNESS}

The results are still valid if we estimate the IV ordered probit model separately for euro-area and non-euro-area countries. Also, if we include less covariates (Table 10 in Appendix) or if we control for the persistence of the strong demand shock, results are similar. The Appendix contains estimation results for the total sample with all five demand categories (Table 9). While we also find a positive impact of wage decreases on employment in the whole sample, the effect of wages is much stronger for the subsample of firms that experience a fall in demand. As an additional robustness check, we used a different instrumental variable, namely a dummy variable indicating if an outside firm level collective agreement is in effect (Table 11). This yields comparable results as our baseline estimation. Furthermore, we can confirm that results are not sensitive to excluding any single country or sector from the estimation sample.

\section{CONCLUDING REMARKS}

One major advantage of the WDN data when exploring wage and employment adjustments is firm-level information on the change in economic conditions during the 2010-to-2013 period. We explore the marginal effects of a change in demand on the probabilities of observing specific wage reactions and find evidence of downward nominal wage rigidity in Europe for the years between 2010 and 2013. Our findings show wage rigidities via two channels: first, collective pay agreements - which are mainly driven by agreements outside the firm (i.e., national or sectoral, rather than more decentralised firm-level agreements) reduce the probability of downward wage adjustment. Given the wide range of collective

\footnotetext{
${ }^{18}$ Tables show the model specification with credit constraints regarding debt refinancing. Results are similar if we include credit constraints regarding financing of investment or working capital instead.
} 
bargaining coverage across countries, this result also implies significantly more downward nominal wage rigidities for countries with larger shares of employees covered by collective pay agreements; second, asymmetric demand elasticities for wages indicate that the rise in the probability of downward base wage responses to a decrease in demand is significantly smaller than the rise in the probability of an upward wage response to an increase in demand.

The paper further analyses the influence of wage reactions to a fall in demand on employment. Estimation results point to a negative effect of downward wage rigidities on employment at the firm level when these rigidities are induced by collective pay agreements. This does not imply that wage rigidities which aim to reduce the possible negative effects of wage cuts on employees' motivation have the same effect. Our results suggest that exit clauses from collective pay agreements in case of demand shocks/recessions could mitigate negative employment effects at the firm level.

An obvious limitation of the data is that it only includes firms that survived during 2010 and 2013. We therefore cannot explore how wage rigidities had an impact on business failures. Further, direct conclusions from our firm-level analysis (which treats the development of demand as exogenous) to the macro level cannot be made, as wage adjustments and the incidence of unemployment have an impact on aggregate demand. 


\section{REFERENCES}

Agell, J. and P. Lundborg (2003), "Survey Evidence on Wage Rigidity and Unemployment: Sweden in the 1990s", The Scandinavian Journal of Economics 105 (1), pp.15-29.

Akerlof, G.A. (1982), "Labor Contracts as Partial Gift Exchange", The Quarterly Journal of Economics 97 (4), pp. 543-569.

Altonji, J. G. and P. J. Devereux (2000), "The Extent and Consequences of Downward Nominal Wage Rigidity", Research in Labor Economics 19, pp. $383-431$.

Amendola, M., J.-L. Gaffard, and F. Saraceno (2004), "Wage Flexibility and Unemployment: The Keynesian Perspective Revisited", Scottish Journal of Political Economy 51 (5), pp. 654-674.

Anderton, R. and Bonthuis, B. (2015), "Downward wage rigidities in the euro area", GEP Research Paper Series, No. 15/09, University of Nottingham, July 2015.

Anderton, R, Hantzsche, A., Savsek, S. and Toth, M (2016), "Sectoral Wage Rigidities and Labour and Product Market Institutions in the Euro Area", Centre for Finance, Credit and Macroeconomics, Working Paper No. 16/01, University of Nottingham, January 2016.

Babecký, J., P. Du Caju, T. Kosma, M. Lawless, J. Messina, and T. Rõõm (2012), "How do European firms adjust their labour costs when nominal wages are rigid?", Labour Economics 19 (5), pp. 792-801.

Barwell, R.D. and M.E. Schweitzer (2007), "The incidence of nominal and real wage rigidities in Great Britain: 1978-98", Economic Journal 117 (524), pp. F553-F569.

Boeri, T., and J. van Ours (2013), "The Economics of Imperfect Labor Markets", Princeton University Press.

Calmfors, L. und $\AA$. Johansson (2006), "Nominal Wage Flexibility, Wage Indexation and Monetary Union", The Economic Journal 116, pp. 283-308.

Card, D. and Hyslop D. (1997) "Does inflation "Grease the Wheels of the Labour Market"?", NBER Chapter in: Reducing Inflation: Motivation and Strategy, University of Chicago Press, pp. 71-122.

Devicienti, F., A. Maida und P. Sestito (2007), "Downward wage rigidity in Italy: Micro-based measures and implications", Economic Journal 117, pp. F530-F552.

Dias, D.A., C.R. Marques and F. Martins (2013), "Wage rigidity and employment adjustment at the firm level: Evidence from survey data", Labour Economics 23, pp. 40-49.

Dickens, W., L. Gotte, E.L. Groshen, S. Holden, J. Messina, M.E. Schweitzer, J. Turunen, and M.E. Ward (2007), "How Wages Change. Micro Evidence from the International Wage Flexibility Project", Journal of Economic Perspectives 21 (2), pp. 195-214. 
DiNardo, J. and D.S. Lee (2004), "Economic impacts of new unionization on private sector employers: 1984-2001", The Quarterly Journal of Economics 119 (4), pp. 1383-1441.

Du Caju, P., T. Kosma, M. Lawless, J. Messina, and T. Rõõm (2015), "Why Firms Avoid Cutting Wages: Survey Evidence from European Firms", ILR Review 68 (4), pp. 862888.

Fabiani S., A. Lamo, J. Messina, and T. Rõõm (2015) "European firm adjustment during times of economic crisis," IZA Journal of Labor Policy 4 (24), pp. 1-28.

Galí, J. and T. Monacelli (2016), "Understanding the Gains from Wage Flexibility: The Exchange Rate Connection", American Economic Review 106, pp. 3829-3868

Hall, R.E. and P.R. Milgrom (2008), "The Limited Influence of Unemployment on the Wage Bargain", American Economic Review 98 (4), pp. 1653-1674.

Holden S. and F. Wulfsberg (2008), "Downward Nominal Wage Rigidity in the OECD", The B.E. Journal of Macroeconomics 8 (1, Advances, Article 15), pp. 1-48.

Howitt, P. (1986), "Wage Flexibility and Employment", Eastern Economic Journal 12 (3), pp. 237-242.

Keynes, J.M. (1936), "The General Theory of Employment, Interest, and Money", London: MacMillan.

Knoppik, C. and T. Beissinger (2009), "Downward nominal wage rigidity in Europe: an analysis of European micro data from the ECHP 1994-2001", Empirical Economics 36 (2), pp. 321-338.

Roodman, D. (2011), "Estimating Fully Observed Recursive Mixed-Process Models with cmp", Stata Journal 11 (2), pp. 159- 206.

Schmitt-Grohé, S. and M. Uribe (2013), Downward Nominal Wage Rigidity and the Case for Temporary Inflation in the Eurozone, Journal of Economic Perspectives 27 (3), pp. 193-211.

Shimer, R. (2012), "Wage rigidities and jobless recoveries", Journal of Monetary Economics 59, pp. S65-S77.

Sojourner, A.J., B.R. Frandsen, R.J. Town, D.C. Grabowski and M.M. Chen (2015), "Impacts of Unionization on Quality and Productivity: Regression Discontinuity Evidence from Nursing Homes", ILR Review 68 (4), pp. 771-806.

Solow, R.M. (1979), "Another Possible Source of Wage Stickiness", Journal of Macroeconomics 1 (1), pp. 79-82.

Stiglitz, J.E. (1974), "Alternative Theories of Wage Determination and Unemployment in LDC's: The Labor Turnover Model", Quarterly Journal of Economics 88, pp. 194-227.

Venn, D. (2009), "Legislation, Collective Bargaining and Enforcement: Updating the OECD Employment Protection Indicators", OECD Social, Employment and Migration Working Papers, No. 89, OECD Publishing. 


\section{APPENDIX}

\section{DESCRIPTIVE STATISTICS}

Table 8: Firm characteristics

\begin{tabular}{|c|c|c|c|}
\hline & & ample & $\begin{array}{l}\text { Only firms with negative } \\
\text { demand shock }\end{array}$ \\
\hline & & 15,368 & 6,758 \\
\hline \multirow[t]{7}{*}{ Sector } & Manufacturing & $28 \%$ & $26 \%$ \\
\hline & Electricity, gas, water & $1 \%$ & $0.3 \%$ \\
\hline & Construction & $6 \%$ & $9 \%$ \\
\hline & Trade & $22 \%$ & $27 \%$ \\
\hline & Business services & $39 \%$ & $36 \%$ \\
\hline & Financial intermediation & $2 \%$ & $2 \%$ \\
\hline & Arts & $1 \%$ & $1 \%$ \\
\hline \multirow[t]{2}{*}{ Ownership at the end of 2013} & Mainly domestic & $79 \%$ & $81 \%$ \\
\hline & Mainly foreign & $21 \%$ & $19 \%$ \\
\hline \multirow[t]{4}{*}{ Size } & less than 19 employees & $17 \%$ & $20 \%$ \\
\hline & 20-49 employees & $16 \%$ & $17 \%$ \\
\hline & 50-199 employees & $27 \%$ & $27 \%$ \\
\hline & 200 employees and + & $40 \%$ & $36 \%$ \\
\hline \multirow[t]{6}{*}{ Payroll composition at the end of 2013} & Lower skilled & $43 \%$ & $45 \%$ \\
\hline & Higher skilled & $57 \%$ & $54 \%$ \\
\hline & Job tenure $>5$ years & $59 \%$ & $63 \%$ \\
\hline & Permanent contracts & $90 \%$ & $90 \%$ \\
\hline & Temporary contracts & $10 \%$ & $9 \%$ \\
\hline & Agency & $1 \%$ & $1 \%$ \\
\hline
\end{tabular}

\section{ASYMMETRIC WAGE RESPONSES: IV ORDERED PROBIT}

There is also evidence in favour of asymmetric demand elasticities for wages in the IV ordered probit model.

Table 9: IV ordered probit estimation with all five demand categories

Marginal effects on the probability of observing the outcome

\begin{tabular}{lccccc}
\hline Wage equation & $\begin{array}{c}(1) \\
\text { base wages } \\
\text { strong decrease }\end{array}$ & $\begin{array}{c}(2) \\
\text { base wages } \\
\text { moderate decrease }\end{array}$ & $\begin{array}{c}(3) \\
\text { base wages } \\
\text { unchanged }\end{array}$ & $\begin{array}{c}(4) \\
\text { base wages } \\
\text { moderate increase }\end{array}$ & $\begin{array}{c}(5) \\
\text { base wages } \\
\text { strong increase }\end{array}$ \\
\hline Collective pay agreement ${ }^{a}$ & $-0.005^{* * *}$ & $-0.013^{* * *}$ & $-0.031^{* * *}$ & $0.037^{* * *}$ & $0.012^{* * * *}$ \\
Demand & $(0.001)$ & $(0.002)$ & $(0.005)$ & $(0.006)$ & $(0.002)$ \\
Strong decrease & $0.015^{* * *}$ & $0.038^{* * *}$ & $0.071^{* * *}$ & $-0.106^{* * *}$ & $-0.018^{* * *}$ \\
Moderate decrease & $(0.002)$ & $(0.004)$ & $(0.007)$ & $(0.011)$ & $(0.002)$ \\
Unchanged (reference) & $0.005^{* * *}$ & $0.014^{* * *}$ & $0.032^{* * *}$ & $-0.042^{* * *}$ & $-0.009^{* * *}$ \\
& $(0.001)$ & $(0.003)$ & $(0.006)$ & $(0.008)$ & $(0.002)$
\end{tabular}




\begin{tabular}{|c|c|c|c|c|c|}
\hline Moderate increase & $\begin{array}{c}-0.007 * * * \\
(0.001)\end{array}$ & $\begin{array}{c}-0.024 * * * \\
(0.002)\end{array}$ & $\begin{array}{c}-0.076^{* * * *} \\
(0.006)\end{array}$ & $\begin{array}{c}0.079 \text { *** } \\
(0.007)\end{array}$ & $\begin{array}{c}0.029 * * * \\
(0.002)\end{array}$ \\
\hline Strong increase & $\begin{array}{c}-0.010^{* * * *} \\
(0.001)\end{array}$ & $\begin{array}{c}-0.036^{* * * *} \\
(0.003)\end{array}$ & $\begin{array}{c}-0.129 * * * \\
(0.011)\end{array}$ & $\begin{array}{c}0.117 * * * \\
(0.008)\end{array}$ & $\begin{array}{c}0.058 * * * \\
(0.007)\end{array}$ \\
\hline \multicolumn{6}{|l|}{ Negative shocks: } \\
\hline Finance & $\begin{array}{c}0.004 * * * \\
(0.001)\end{array}$ & $\begin{array}{c}0.012 * * * \\
(0.003)\end{array}$ & $\begin{array}{c}0.026 \text { **** } \\
(0.006)\end{array}$ & $\begin{array}{c}-0.033^{* * * *} \\
(0.007)\end{array}$ & $\begin{array}{c}-0.009 * * * \\
(0.002)\end{array}$ \\
\hline Customers & $\begin{array}{c}0.000 \\
(0.001)\end{array}$ & $\begin{array}{c}0.001 \\
(0.002)\end{array}$ & $\begin{array}{c}0.002 \\
(0.005)\end{array}$ & $\begin{array}{l}-0.003 \\
(0.006)\end{array}$ & $\begin{array}{l}-0.001 \\
(0.002)\end{array}$ \\
\hline Supplies & $\begin{array}{c}0.002 \\
(0.001)\end{array}$ & $\begin{array}{c}0.004 \\
(0.003)\end{array}$ & $\begin{array}{c}0.010 \\
(0.006)\end{array}$ & $\begin{array}{l}-0.012 \\
(0.008)\end{array}$ & $\begin{array}{l}-0.004 \\
(0.002)\end{array}$ \\
\hline \multicolumn{6}{|l|}{ Share of workers: } \\
\hline Permanent contract & $\begin{array}{c}0.003 \\
(0.002)\end{array}$ & $\begin{array}{c}0.008 \\
(0.005)\end{array}$ & $\begin{array}{c}0.017 \\
(0.011)\end{array}$ & $\begin{array}{l}-0.021 \\
(0.014)\end{array}$ & $\begin{array}{l}-0.007 \\
(0.004)\end{array}$ \\
\hline Tenure $>5$ years & $\begin{array}{c}0.007 * * * * \\
(0.001)\end{array}$ & $\begin{array}{c}0.017 * * * \\
(0.003)\end{array}$ & $\begin{array}{c}0.040 * * * \\
(0.007)\end{array}$ & $\begin{array}{c}-0.049 * * * \\
(0.009)\end{array}$ & $\begin{array}{c}-0.015 * * * \\
(0.003)\end{array}$ \\
\hline Higher skilled & $\begin{array}{c}0.001 \\
(0.001)\end{array}$ & $\begin{array}{c}0.004 \\
(0.003)\end{array}$ & $\begin{array}{c}0.008 \\
(0.006)\end{array}$ & $\begin{array}{l}-0.010 \\
(0.008)\end{array}$ & $\begin{array}{l}-0.003 \\
(0.002)\end{array}$ \\
\hline Manual & $\begin{array}{c}-0.007 * * * \\
(0.001)\end{array}$ & $\begin{array}{c}-0.019 * * * \\
(0.003)\end{array}$ & $\begin{array}{c}-0.042 * * * \\
(0.007)\end{array}$ & $\begin{array}{c}0.052 * * * \\
(0.008)\end{array}$ & $\begin{array}{c}0.016 * * * \\
(0.003)\end{array}$ \\
\hline Foreign ownership & $\begin{array}{c}-0.003 * * * \\
(0.001)\end{array}$ & $\begin{array}{c}-0.009 * * * \\
(0.002)\end{array}$ & $\begin{array}{c}-0.022 * * * \\
(0.005)\end{array}$ & $\begin{array}{c}0.025 * * * \\
(0.006)\end{array}$ & $\begin{array}{c}0.008 * * * * \\
(0.002)\end{array}$ \\
\hline Bonuses & $\begin{array}{c}-0.004 * * * \\
(0.001)\end{array}$ & $\begin{array}{c}-0.009 * * * \\
(0.002)\end{array}$ & $\begin{array}{c}-0.021^{* * *} * \\
(0.005)\end{array}$ & $\begin{array}{c}0.026 * * * \\
(0.006)\end{array}$ & $\begin{array}{c}0.008^{* * * *} \\
(0.002)\end{array}$ \\
\hline Labour cost share & $\begin{array}{c}-0.003^{*} \\
(0.002)\end{array}$ & $\begin{array}{c}-0.009^{*} \\
(0.004)\end{array}$ & $\begin{array}{c}-0.019^{*} \\
(0.010)\end{array}$ & $\begin{array}{l}0.024 * \\
(0.012)\end{array}$ & $\begin{array}{l}0.007 * \\
(0.004)\end{array}$ \\
\hline Firing costs & $\begin{array}{c}-0.003 * * * \\
(0.001)\end{array}$ & $\begin{array}{c}-0.009 * * * \\
(0.002)\end{array}$ & $\begin{array}{c}-0.020 * * * \\
(0.004)\end{array}$ & $\begin{array}{c}0.025^{* * *} * \\
(0.005)\end{array}$ & $\begin{array}{c}0.008 * * * \\
(0.002)\end{array}$ \\
\hline Credit constraint $^{\mathrm{b}}$ & $\begin{array}{c}0.003 * * * \\
(0.001)\end{array}$ & $\begin{array}{c}0.009 * * * \\
(0.002)\end{array}$ & $\begin{array}{c}0.019 * * * \\
(0.005)\end{array}$ & $\begin{array}{c}-0.024 * * * \\
(0.006)\end{array}$ & $\begin{array}{c}-0.007 * * * \\
(0.002)\end{array}$ \\
\hline VARIABLES & $\begin{array}{c}(1) \\
\text { employment } \\
\text { strong decrease }\end{array}$ & $\begin{array}{c}(2) \\
\text { employment } \\
\text { moderate decrease }\end{array}$ & $\begin{array}{c}\text { (3) } \\
\text { employment } \\
\text { unchanged } \\
\end{array}$ & $\begin{array}{c}(4) \\
\text { employment } \\
\text { moderate increase }\end{array}$ & $\begin{array}{c}(5) \\
\text { employment } \\
\text { strong increase } \\
\end{array}$ \\
\hline \multicolumn{6}{|l|}{ Base wages: } \\
\hline Strong decrease & $\begin{array}{l}-0.017^{*} \\
(0.009)\end{array}$ & $\begin{array}{l}-0.032^{*} \\
(0.018)\end{array}$ & $\begin{array}{l}-0.023 \\
(0.018)\end{array}$ & $\begin{array}{c}0.036^{* *} \\
(0.018)\end{array}$ & $\begin{array}{c}0.036 \\
(0.027)\end{array}$ \\
\hline Moderate decrease & $\begin{array}{l}-0.019^{* * * *} \\
(0.004)\end{array}$ & $\begin{array}{c}-0.037 * * * \\
(0.008)\end{array}$ & $\begin{array}{c}-0.028 * * * \\
(0.010)\end{array}$ & $\begin{array}{c}0.041^{* * * *} \\
(0.007)\end{array}$ & $\begin{array}{c}0.043 * * * \\
(0.016)\end{array}$ \\
\hline \multicolumn{6}{|l|}{ Unchanged (reference) } \\
\hline Moderate increase & $\begin{array}{c}0.056 * * * \\
(0.011)\end{array}$ & $\begin{array}{c}0.071 * * * \\
(0.009)\end{array}$ & $\begin{array}{c}0.016 * * * \\
(0.003)\end{array}$ & $\begin{array}{c}-0.090 * * * \\
(0.011)\end{array}$ & $\begin{array}{c}-0.053 * * * \\
(0.012)\end{array}$ \\
\hline Strong increase & $\begin{array}{c}0.196 * * * \\
(0.046)\end{array}$ & $\begin{array}{c}0.148 * * * \\
(0.008)\end{array}$ & $\begin{array}{c}-0.045^{* * * *} \\
(0.016)\end{array}$ & $\begin{array}{c}-0.210 * * * \\
(0.023)\end{array}$ & $\begin{array}{c}-0.089 * * * \\
(0.015)\end{array}$ \\
\hline \multicolumn{6}{|l|}{ Demand } \\
\hline Strong decrease & $\begin{array}{c}0.154 * * * \\
(0.010)\end{array}$ & $\begin{array}{c}0.145^{* * * *} \\
(0.012)\end{array}$ & $\begin{array}{c}-0.073^{* * *} \\
(0.007)\end{array}$ & $\begin{array}{c}-0.185 * * * \\
(0.008)\end{array}$ & $\begin{array}{c}-0.042 * * * \\
(0.005)\end{array}$ \\
\hline Moderate decrease & $\begin{array}{c}0.044 * * * \\
(0.004)\end{array}$ & $\begin{array}{c}0.066 * * * \\
(0.006)\end{array}$ & $\begin{array}{l}-0.003^{*} \\
(0.001)\end{array}$ & $\begin{array}{c}-0.083 * * * \\
(0.007)\end{array}$ & $\begin{array}{c}-0.025 * * * \\
(0.003)\end{array}$ \\
\hline \multicolumn{6}{|l|}{ Unchanged (reference) } \\
\hline Moderate increase & $\begin{array}{c}-0.032 * * * \\
(0.004)\end{array}$ & $\begin{array}{c}-0.080 * * * \\
(0.005)\end{array}$ & $\begin{array}{c}-0.053 * * * \\
(0.004)\end{array}$ & $\begin{array}{c}0.105 * * * \\
(0.008)\end{array}$ & $\begin{array}{c}0.060 * * * \\
(0.006)\end{array}$ \\
\hline Strong increase & $\begin{array}{c}-0.048 * * * \\
(0.006)\end{array}$ & $\begin{array}{c}-0.143 * * * \\
(0.006)\end{array}$ & $\begin{array}{c}-0.166^{* * *} \\
(0.013)\end{array}$ & $\begin{array}{c}0.173^{* * * *} \\
(0.013)\end{array}$ & $\begin{array}{c}0.184 * * * \\
(0.016)\end{array}$ \\
\hline \multicolumn{6}{|l|}{ Negative shocks: } \\
\hline Finance & $\begin{array}{c}0.013 * * * \\
(0.003)\end{array}$ & $\begin{array}{c}0.016 * * * \\
(0.004)\end{array}$ & $\begin{array}{c}0.002 * * * \\
(0.000)\end{array}$ & $\begin{array}{c}-0.021 * * * \\
(0.005)\end{array}$ & $\begin{array}{c}-0.010 * * * \\
(0.003)\end{array}$ \\
\hline Customers & $\begin{array}{l}-0.002 \\
(0.003)\end{array}$ & $\begin{array}{l}-0.002 \\
(0.003)\end{array}$ & $\begin{array}{l}-0.000 \\
(0.001)\end{array}$ & $\begin{array}{c}0.003 \\
(0.004)\end{array}$ & $\begin{array}{c}0.001 \\
(0.002)\end{array}$ \\
\hline
\end{tabular}




\begin{tabular}{|c|c|c|c|c|c|}
\hline Supplies & $\begin{array}{c}0.013 * * * \\
(0.004)\end{array}$ & $\begin{array}{c}0.016^{* * * *} \\
(0.005)\end{array}$ & $\begin{array}{c}0.002 * * * \\
(0.000)\end{array}$ & $\begin{array}{c}-0.021^{* * *} \\
(0.006)\end{array}$ & $\begin{array}{c}-0.010 * * * \\
(0.003)\end{array}$ \\
\hline \multicolumn{6}{|l|}{ Share of workers: } \\
\hline Permanent contract & $\begin{array}{c}0.022 * * * \\
(0.006)\end{array}$ & $\begin{array}{c}0.029 * * * \\
(0.008)\end{array}$ & $\begin{array}{c}0.005 * * * \\
(0.001)\end{array}$ & $\begin{array}{c}-0.037 * * * \\
(0.010)\end{array}$ & $\begin{array}{c}-0.019 * * * \\
(0.005)\end{array}$ \\
\hline Tenure $>5$ years & $\begin{array}{c}0.093 * * * \\
(0.006)\end{array}$ & $\begin{array}{c}0.120^{* * *} \\
(0.008)\end{array}$ & $\begin{array}{c}0.020 * * * \\
(0.002)\end{array}$ & $\begin{array}{c}-0.154 * * * \\
(0.009)\end{array}$ & $\begin{array}{c}-0.078 * * * \\
(0.005)\end{array}$ \\
\hline Higher skilled & $\begin{array}{l}-0.002 \\
(0.003)\end{array}$ & $\begin{array}{l}-0.003 \\
(0.004)\end{array}$ & $\begin{array}{l}-0.000 \\
(0.001)\end{array}$ & $\begin{array}{c}0.003 \\
(0.006)\end{array}$ & $\begin{array}{c}0.002 \\
(0.003)\end{array}$ \\
\hline Manual & $\begin{array}{l}-0.007 * \\
(0.004)\end{array}$ & $\begin{array}{l}-0.009^{*} \\
(0.005)\end{array}$ & $\begin{array}{l}-0.001 * \\
(0.001)\end{array}$ & $\begin{array}{l}0.012^{*} \\
(0.006)\end{array}$ & $\begin{array}{l}0.006^{*} \\
(0.003)\end{array}$ \\
\hline Foreign ownership & $\begin{array}{l}-0.004 \\
(0.003)\end{array}$ & $\begin{array}{l}-0.006 \\
(0.004)\end{array}$ & $\begin{array}{l}-0.001 \\
(0.001)\end{array}$ & $\begin{array}{c}0.007 \\
(0.005)\end{array}$ & $\begin{array}{c}0.004 \\
(0.003)\end{array}$ \\
\hline Bonuses & $\begin{array}{c}-0.014 * * * \\
(0.003)\end{array}$ & $\begin{array}{c}-0.018^{* * * *} \\
(0.003)\end{array}$ & $\begin{array}{c}-0.002 * * * \\
(0.000)\end{array}$ & $\begin{array}{c}0.023 * * * \\
(0.004)\end{array}$ & $\begin{array}{c}0.011^{* * * *} \\
(0.002)\end{array}$ \\
\hline Labour cost share & $\begin{array}{c}0.007 \\
(0.006)\end{array}$ & $\begin{array}{c}0.009 \\
(0.007)\end{array}$ & $\begin{array}{c}0.001 \\
(0.001)\end{array}$ & $\begin{array}{c}-0.011 \\
(0.009)\end{array}$ & $\begin{array}{c}-0.006 \\
(0.005)\end{array}$ \\
\hline Firing costs & $\begin{array}{l}-0.000 \\
(0.002)\end{array}$ & $\begin{array}{l}-0.000 \\
(0.003)\end{array}$ & $\begin{array}{l}-0.000 \\
(0.001)\end{array}$ & $\begin{array}{c}0.000 \\
(0.004)\end{array}$ & $\begin{array}{c}0.000 \\
(0.002)\end{array}$ \\
\hline Credit constraint $^{\mathrm{b}}$ & $\begin{array}{c}0.013 * * * \\
(0.003)\end{array}$ & $\begin{array}{c}0.017 * * * \\
(0.004)\end{array}$ & $\begin{array}{c}0.002 * * * \\
(0.000)\end{array}$ & $\begin{array}{c}-0.021 * * * \\
(0.005)\end{array}$ & $\begin{array}{c}-0.010 * * * \\
(0.002)\end{array}$ \\
\hline $\begin{array}{l}\text { Observations } \\
\text { p-value } \\
\text { rho }\end{array}$ & $\begin{array}{c}15,368 \\
0.000 \\
0.585^{* * *}\end{array}$ & & & & \\
\hline
\end{tabular}

Note: Firm size, sector and country dummies included. The IV ordered probit model was estimated using the Stata command cmp (Roodman, 2011). Marginal effect for indicator variables is the discrete change from the base level.

\section{Robustness of the IV ORdered Probit ESTIMATION}

Table 10: Less covariates; only firms with negative demand shock

Marginal effects on the probability of observing the outcome

\begin{tabular}{|c|c|c|c|c|c|}
\hline $\begin{array}{l}\text { Wage equation } \\
\text { VARIABLES }\end{array}$ & $\begin{array}{c}(1) \\
\text { base wages } \\
\text { strong decrease }\end{array}$ & $\begin{array}{c}(2) \\
\text { base wages } \\
\text { moderate decrease }\end{array}$ & $\begin{array}{c}\text { (3) } \\
\text { base wages } \\
\text { unchanged }\end{array}$ & $\begin{array}{c}(4) \\
\text { base wages } \\
\text { moderate increase }\end{array}$ & $\begin{array}{c}5) \\
\text { base wages } \\
\text { strong increase }\end{array}$ \\
\hline Collective pay agreement ${ }^{\mathrm{a}}$ & $\begin{array}{c}-0.008 * * * * \\
(0.002)\end{array}$ & $\begin{array}{c}-0.017 * * * * \\
(0.004)\end{array}$ & $\begin{array}{c}-0.019 * * * \\
(0.005)\end{array}$ & $\begin{array}{c}0.036 * * * \\
(0.009)\end{array}$ & $\begin{array}{c}0.008 * * * * \\
(0.002)\end{array}$ \\
\hline Strong demand shock & $\begin{array}{c}0.017 * * * \\
(0.002)\end{array}$ & $\begin{array}{c}0.036 * * * \\
(0.004)\end{array}$ & $\begin{array}{c}0.037 * * * \\
(0.004)\end{array}$ & $\begin{array}{c}-0.074 * * * \\
(0.009)\end{array}$ & $\begin{array}{c}-0.015 * * * \\
(0.002)\end{array}$ \\
\hline $\begin{array}{l}\text { Employment equation } \\
\text { VARIABLES }\end{array}$ & $\begin{array}{c}(1) \\
\text { employment } \\
\text { strong decrease }\end{array}$ & $\begin{array}{c}(2) \\
\text { employment } \\
\text { moderate decrease }\end{array}$ & $\begin{array}{c}3) \\
\text { employment } \\
\text { unchanged }\end{array}$ & $\begin{array}{c}\text { (4) } \\
\text { employment } \\
\text { moderate increase }\end{array}$ & $\begin{array}{c}(5) \\
\text { employment } \\
\text { strong increase }\end{array}$ \\
\hline Base wages: & & & & & \\
\hline Strong decrease & $\begin{array}{c}-0.102 * * * * \\
(0.011)\end{array}$ & $\begin{array}{c}-0.133 * * * \\
(0.009)\end{array}$ & $\begin{array}{c}-0.097 * * * \\
(0.021)\end{array}$ & $\begin{array}{c}0.077 * * * \\
(0.021)\end{array}$ & $\begin{array}{c}0.256 \text { *** } \\
(0.057)\end{array}$ \\
\hline Moderate decrease & $\begin{array}{c}-0.081 * * * \\
(0.009)\end{array}$ & $\begin{array}{c}-0.092 * * * \\
(0.005)\end{array}$ & $\begin{array}{c}-0.048 * * * \\
(0.010)\end{array}$ & $\begin{array}{c}0.072 * * * \\
(0.009)\end{array}$ & $\begin{array}{c}0.150 * * * \\
(0.028)\end{array}$ \\
\hline
\end{tabular}




\begin{tabular}{|c|c|c|c|c|c|}
\hline Moderate increase & $\begin{array}{c}0.218^{* * * *} \\
(0.024)\end{array}$ & $\begin{array}{c}0.074 * * * \\
(0.006)\end{array}$ & $\begin{array}{c}-0.066 * * * \\
(0.003)\end{array}$ & $\begin{array}{c}-0.134 * * * * \\
(0.006)\end{array}$ & $\begin{array}{c}-0.091 \text { *** } \\
(0.016)\end{array}$ \\
\hline Strong increase & $\begin{array}{c}0.645 * * * \\
(0.042)\end{array}$ & $\begin{array}{c}-0.051 * * \\
(0.022)\end{array}$ & $\begin{array}{c}-0.249^{* * * *} \\
(0.008)\end{array}$ & $\begin{array}{c}-0.229 * * * \\
(0.008)\end{array}$ & $\begin{array}{c}-0.116^{* * *} \\
(0.019)\end{array}$ \\
\hline Strong demand shock & $\begin{array}{c}0.140 * * * \\
(0.008)\end{array}$ & $\begin{array}{c}0.040 * * * \\
(0.007)\end{array}$ & $\begin{array}{c}-0.039 * * * \\
(0.006)\end{array}$ & $\begin{array}{c}-0.079 * * * \\
(0.008)\end{array}$ & $\begin{array}{c}-0.063 * * * \\
(0.007)\end{array}$ \\
\hline $\begin{array}{l}\text { Observations } \\
\text { p-value } \\
\text { rho }\end{array}$ & $\begin{array}{c}6,758 \\
0.000 \\
0.827 * * *\end{array}$ & & & & \\
\hline
\end{tabular}

Note: Firm size, sector and country dummies included. The IV ordered probit model was estimated using the Stata command cmp (Roodman, 2011). Marginal effect for indicator variables is the discrete change from the base level.

Table 11: IV ordered probit estimation: dummy variable indicating outside firm level collective pay agreement as instrumental variable; only firms with negative demand shock

Marginal effects on the probability of observing the outcome

\begin{tabular}{|c|c|c|c|c|c|}
\hline $\begin{array}{l}\text { Wage equation } \\
\text { VARIABLES }\end{array}$ & $\begin{array}{c}(1) \\
\text { base wages } \\
\text { strong decrease }\end{array}$ & $\begin{array}{c}(2) \\
\text { base wages } \\
\text { moderate decrease }\end{array}$ & $\begin{array}{c}\text { (3) } \\
\text { base wages } \\
\text { unchanged }\end{array}$ & $\begin{array}{c}\text { (4) } \\
\text { base wages } \\
\text { moderate increase }\end{array}$ & $\begin{array}{c}\text { (5) } \\
\text { base wages } \\
\text { strong increase }\end{array}$ \\
\hline Outside firm level agreement & $\begin{array}{c}-0.005^{* * * *} \\
(0.002)\end{array}$ & $\begin{array}{c}-0.010 * * * \\
(0.004)\end{array}$ & $\begin{array}{c}-0.012 * * * \\
(0.004)\end{array}$ & $\begin{array}{c}0.022 * * * \\
(0.008)\end{array}$ & $\begin{array}{c}0.005^{* * * *} \\
(0.002)\end{array}$ \\
\hline Strong demand shock & $\begin{array}{c}0.012 * * * \\
(0.002)\end{array}$ & $\begin{array}{c}0.027 * * * \\
(0.004)\end{array}$ & $\begin{array}{c}0.028^{* * *} * \\
(0.004)\end{array}$ & $\begin{array}{c}-0.056^{* * * *} \\
(0.009)\end{array}$ & $\begin{array}{c}-0.012^{* * * *} \\
(0.002)\end{array}$ \\
\hline \multicolumn{6}{|l|}{ Negative shocks: } \\
\hline Finance & $\begin{array}{c}0.008 * * * \\
(0.002)\end{array}$ & $\begin{array}{c}0.017 * * * \\
(0.005)\end{array}$ & $\begin{array}{c}0.019^{* * * *} \\
(0.005)\end{array}$ & $\begin{array}{c}-0.036^{* * * *} \\
(0.010)\end{array}$ & $\begin{array}{c}-0.008^{* * * *} \\
(0.002)\end{array}$ \\
\hline Customers & $\begin{array}{c}0.003 \\
(0.002)\end{array}$ & $\begin{array}{c}0.006 \\
(0.004)\end{array}$ & $\begin{array}{c}0.007 \\
(0.005)\end{array}$ & $\begin{array}{l}-0.013 \\
(0.009)\end{array}$ & $\begin{array}{l}-0.003 \\
(0.002)\end{array}$ \\
\hline Supplies & $\begin{array}{c}0.002 \\
(0.002)\end{array}$ & $\begin{array}{c}0.005 \\
(0.005)\end{array}$ & $\begin{array}{c}0.005 \\
(0.005)\end{array}$ & $\begin{array}{l}-0.010 \\
(0.010)\end{array}$ & $\begin{array}{l}-0.002 \\
(0.002)\end{array}$ \\
\hline \multicolumn{6}{|l|}{ Share of workers: } \\
\hline Permanent contract & $\begin{array}{c}-0.001 \\
(0.006)\end{array}$ & $\begin{array}{l}-0.003 \\
(0.012)\end{array}$ & $\begin{array}{l}-0.003 \\
(0.014)\end{array}$ & $\begin{array}{c}0.006 \\
(0.026)\end{array}$ & $\begin{array}{c}0.001 \\
(0.006)\end{array}$ \\
\hline Tenure $>5$ years & $\begin{array}{c}0.014 * * * \\
(0.003)\end{array}$ & $\begin{array}{c}0.031 * * * * \\
(0.007)\end{array}$ & $\begin{array}{c}0.035^{* * * *} \\
(0.008)\end{array}$ & $\begin{array}{c}-0.065 * * * \\
(0.015)\end{array}$ & $\begin{array}{c}-0.015^{* * *} \\
(0.004)\end{array}$ \\
\hline Higher skilled & $\begin{array}{c}0.006 * * \\
(0.003)\end{array}$ & $\begin{array}{c}0.014 * * \\
(0.006)\end{array}$ & $\begin{array}{c}0.016^{* *} \\
(0.007)\end{array}$ & $\begin{array}{c}-0.030 * * \\
(0.012)\end{array}$ & $\begin{array}{c}-0.007 * * \\
(0.003)\end{array}$ \\
\hline Manual & $\begin{array}{c}-0.018 * * * \\
(0.003)\end{array}$ & $\begin{array}{c}-0.040^{* * * *} \\
(0.006)\end{array}$ & $\begin{array}{c}-0.046 \text { **** } \\
(0.007)\end{array}$ & $\begin{array}{c}0.085^{* * * *} \\
(0.013)\end{array}$ & $\begin{array}{c}0.019 \text { *** } \\
(0.003)\end{array}$ \\
\hline Foreign ownership & $\begin{array}{c}-0.004^{*} \\
(0.002)\end{array}$ & $\begin{array}{c}-0.009^{*} \\
(0.005)\end{array}$ & $\begin{array}{l}-0.011^{*} \\
(0.007)\end{array}$ & $\begin{array}{l}0.020^{*} \\
(0.012)\end{array}$ & $\begin{array}{l}0.005^{*} \\
(0.003)\end{array}$ \\
\hline Bonuses & $\begin{array}{c}-0.008 * * * \\
(0.002)\end{array}$ & $\begin{array}{c}-0.017 * * * * \\
(0.004)\end{array}$ & $\begin{array}{c}-0.018 * * * \\
(0.005)\end{array}$ & $\begin{array}{c}0.035^{* * * *} \\
(0.009)\end{array}$ & $\begin{array}{c}0.008 * * * \\
(0.002)\end{array}$ \\
\hline Labour cost share & $\begin{array}{c}-0.004 \\
(0.004)\end{array}$ & $\begin{array}{l}-0.009 \\
(0.010)\end{array}$ & $\begin{array}{l}-0.010 \\
(0.011)\end{array}$ & $\begin{array}{c}0.019 \\
(0.020)\end{array}$ & $\begin{array}{c}0.004 \\
(0.005)\end{array}$ \\
\hline Firing costs & $\begin{array}{c}-0.007 * * * * \\
(0.002)\end{array}$ & $\begin{array}{c}-0.014 * * * \\
(0.004)\end{array}$ & $\begin{array}{c}-0.016^{* * * *} \\
(0.004)\end{array}$ & $\begin{array}{c}0.030^{* * * *} \\
(0.008)\end{array}$ & $\begin{array}{c}0.007 * * * \\
(0.002)\end{array}$ \\
\hline Credit constraint ${ }^{\mathrm{a}}$ & $\begin{array}{c}0.008 * * * \\
(0.002)\end{array}$ & $\begin{array}{c}0.018 * * * \\
(0.004)\end{array}$ & $\begin{array}{c}0.020 * * * \\
(0.005)\end{array}$ & $\begin{array}{c}-0.038 * * * \\
(0.009)\end{array}$ & $\begin{array}{c}-0.008 * * * \\
(0.002)\end{array}$ \\
\hline
\end{tabular}




\begin{tabular}{|c|c|c|c|c|c|}
\hline $\begin{array}{l}\text { Employment equation } \\
\text { VARIABLES }\end{array}$ & $\begin{array}{c}\text { (1) } \\
\text { employment } \\
\text { strong decrease }\end{array}$ & $\begin{array}{c}(2) \\
\text { employment } \\
\text { moderate decrease }\end{array}$ & $\begin{array}{c}\text { (3) } \\
\text { employment } \\
\text { unchanged }\end{array}$ & $\begin{array}{c}(4) \\
\text { employment } \\
\text { moderate increase }\end{array}$ & $\begin{array}{c}(5) \\
\text { employment } \\
\text { strong increase }\end{array}$ \\
\hline \multicolumn{6}{|l|}{ Base wages: } \\
\hline Strong decrease & $\begin{array}{c}-0.091 * * * \\
(0.015)\end{array}$ & $\begin{array}{c}-0.126^{* * * *} \\
(0.014)\end{array}$ & $\begin{array}{c}-0.075^{* *} \\
(0.031)\end{array}$ & $\begin{array}{c}0.097 * * * \\
(0.016)\end{array}$ & $\begin{array}{c}0.195^{* * *} * \\
(0.072)\end{array}$ \\
\hline Moderate decrease & $\begin{array}{c}-0.072 * * * \\
(0.011)\end{array}$ & $\begin{array}{c}-0.089 * * * \\
(0.007)\end{array}$ & $\begin{array}{c}-0.037 * * * \\
(0.014)\end{array}$ & $\begin{array}{c}0.080 * * * \\
(0.008)\end{array}$ & $\begin{array}{c}0.118 * * * \\
(0.035)\end{array}$ \\
\hline \multicolumn{6}{|l|}{ Unchanged (reference) } \\
\hline Moderate increase & $\begin{array}{c}0.189 * * * \\
(0.032)\end{array}$ & $\begin{array}{c}0.078 * * * \\
(0.005)\end{array}$ & $\begin{array}{c}-0.066 * * * \\
(0.003)\end{array}$ & $\begin{array}{c}-0.128 * * * \\
(0.010)\end{array}$ & $\begin{array}{c}-0.073^{* * * *} \\
(0.019)\end{array}$ \\
\hline Strong increase & $\begin{array}{c}0.587 * * * \\
(0.067)\end{array}$ & $\begin{array}{l}-0.021 \\
(0.034)\end{array}$ & $\begin{array}{c}-0.249 * * * \\
(0.009)\end{array}$ & $\begin{array}{c}-0.222 * * * \\
(0.011)\end{array}$ & $\begin{array}{c}-0.095 * * * \\
(0.022)\end{array}$ \\
\hline Strong demand shock & $\begin{array}{c}0.119 * * * \\
(0.008)\end{array}$ & $\begin{array}{c}0.044 * * * \\
(0.010)\end{array}$ & $\begin{array}{c}-0.039 * * * \\
(0.008)\end{array}$ & $\begin{array}{c}-0.076 \text { *** } \\
(0.009)\end{array}$ & $\begin{array}{c}-0.047 * * * * \\
(0.007)\end{array}$ \\
\hline \multicolumn{6}{|l|}{ Negative shocks: } \\
\hline Finance & $\begin{array}{c}0.027 * * * \\
(0.008)\end{array}$ & $\begin{array}{c}0.012 * * * \\
(0.004)\end{array}$ & $\begin{array}{c}-0.008^{* * *} * \\
(0.002)\end{array}$ & $\begin{array}{c}-0.018 * * * * \\
(0.005)\end{array}$ & $\begin{array}{c}-0.013^{* * * *} \\
(0.004)\end{array}$ \\
\hline Customers & $\begin{array}{l}-0.001 \\
(0.007)\end{array}$ & $\begin{array}{l}-0.000 \\
(0.003)\end{array}$ & $\begin{array}{c}0.000 \\
(0.002)\end{array}$ & $\begin{array}{c}0.001 \\
(0.005)\end{array}$ & $\begin{array}{c}0.000 \\
(0.003)\end{array}$ \\
\hline Supplies & $\begin{array}{l}0.015^{*} \\
(0.008)\end{array}$ & $\begin{array}{l}0.006 * \\
(0.004)\end{array}$ & $\begin{array}{c}-0.004 * \\
(0.002)\end{array}$ & $\begin{array}{l}-0.010^{*} \\
(0.005)\end{array}$ & $\begin{array}{l}-0.007 * \\
(0.004)\end{array}$ \\
\hline \multicolumn{6}{|l|}{ Share of workers: } \\
\hline Permanent contract & $\begin{array}{c}0.024 \\
(0.020)\end{array}$ & $\begin{array}{c}0.011 \\
(0.009)\end{array}$ & $\begin{array}{l}-0.007 \\
(0.006)\end{array}$ & $\begin{array}{l}-0.016 \\
(0.014)\end{array}$ & $\begin{array}{l}-0.012 \\
(0.010)\end{array}$ \\
\hline Tenure $>5$ years & $\begin{array}{c}0.138 * * * \\
(0.012)\end{array}$ & $\begin{array}{c}0.061 * * * \\
(0.013)\end{array}$ & $\begin{array}{c}-0.038 * * * \\
(0.008)\end{array}$ & $\begin{array}{c}-0.094 * * * \\
(0.013)\end{array}$ & $\begin{array}{c}-0.067 * * * \\
(0.010)\end{array}$ \\
\hline Higher skilled & $\begin{array}{c}0.010 \\
(0.010)\end{array}$ & $\begin{array}{c}0.004 \\
(0.004)\end{array}$ & $\begin{array}{l}-0.003 \\
(0.003)\end{array}$ & $\begin{array}{l}-0.007 \\
(0.007)\end{array}$ & $\begin{array}{l}-0.005 \\
(0.005)\end{array}$ \\
\hline Manual & $\begin{array}{c}-0.040 * * * \\
(0.012)\end{array}$ & $\begin{array}{c}-0.018 * * * \\
(0.005)\end{array}$ & $\begin{array}{c}0.011 * * * \\
(0.003)\end{array}$ & $\begin{array}{c}0.027 * * * \\
(0.007)\end{array}$ & $\begin{array}{c}0.019 * * * \\
(0.007)\end{array}$ \\
\hline Foreign ownership & $\begin{array}{l}-0.003 \\
(0.010)\end{array}$ & $\begin{array}{c}-0.001 \\
(0.004)\end{array}$ & $\begin{array}{c}0.001 \\
(0.003)\end{array}$ & $\begin{array}{c}0.002 \\
(0.007)\end{array}$ & $\begin{array}{c}0.002 \\
(0.005)\end{array}$ \\
\hline Bonuses & $\begin{array}{c}-0.025 * * * \\
(0.007)\end{array}$ & $\begin{array}{c}-0.011 * * * \\
(0.003)\end{array}$ & $\begin{array}{c}0.007 * * * \\
(0.002)\end{array}$ & $\begin{array}{c}0.017 * * * \\
(0.005)\end{array}$ & $\begin{array}{c}0.012 * * * \\
(0.004)\end{array}$ \\
\hline Labour cost share & $\begin{array}{l}0.031^{*} \\
(0.016)\end{array}$ & $\begin{array}{l}0.014 * \\
(0.008)\end{array}$ & $\begin{array}{l}-0.008^{*} \\
(0.005)\end{array}$ & $\begin{array}{l}-0.021^{*} \\
(0.012)\end{array}$ & $\begin{array}{l}-0.015^{*} \\
(0.008)\end{array}$ \\
\hline Firing costs & $\begin{array}{l}-0.010 \\
(0.007)\end{array}$ & $\begin{array}{c}-0.004 \\
(0.003)\end{array}$ & $\begin{array}{c}0.003 \\
(0.002)\end{array}$ & $\begin{array}{c}0.007 \\
(0.004)\end{array}$ & $\begin{array}{c}0.005 \\
(0.004)\end{array}$ \\
\hline Credit constraint ${ }^{\mathrm{a}}$ & $\begin{array}{c}0.037 * * * * \\
(0.008)\end{array}$ & $\begin{array}{c}0.016 * * * * \\
(0.004)\end{array}$ & $\begin{array}{c}-0.011 * * * \\
(0.003)\end{array}$ & $\begin{array}{c}-0.025 * * * * \\
(0.005)\end{array}$ & $\begin{array}{c}-0.017 * * * \\
(0.004)\end{array}$ \\
\hline Observations & 6,758 & & & & \\
\hline p-value & 0.000 & & & & \\
\hline rho & $0.783 * * *$ & & & & \\
\hline
\end{tabular}

Note: Firm size, sector and country dummies included. The IV ordered probit model was estimated using the Stata command cmp written by Roodman (2011). Marginal effect for indicator variables is the discrete change from the base level. 